\title{
Do presente para o passado: a variação lexical em Minas Gerais a partir de corpora geolinguísticos sobre brinquedos infantis
}

\section{From the present to the past: lexical variation in Minas Gerais from Geolinguistic corpora regarding children's toys}

\author{
Valter Pereira Romano \\ UFLA - Universidade Federal de Lavras \\ valter.romano@hotmail.com \\ Rodrigo Duarte Seabra \\ UNIFEI - Universidade Federal de Itajubá \\ rdsea@hotmail.com
}

Resumo: Este artigo apresenta um estudo sobre a variação lexical em Minas Gerais considerando dois recortes sincrônicos, década de 1970 e início da segunda década do século XXI. Objetiva-se discutir aspectos da variação e mudança linguística em tempo real e tempo aparente e a proposição de áreas lexicais no território mineiro a partir das divisões dialetais propostas por outros estudiosos. Para tanto, foram selecionadas duas cartas linguísticas do Esboço de um Atlas Linguístico de Minas Gerais e dados do Projeto Atlas Linguístico do Brasil no que se refere às variantes que recobrem os conceitos da bolinha de gude estilingue. Os dados são tratados quantitativa e qualitativamente por meio de gráficos, tabelas, cartas linguísticas e a interpretação dos resultados observados correlacionando-os a outros estudos. Dentre as conclusões, observa-se a importância de conjugar o estudo em tempo real ao de tempo aparente o 
que pode dar indícios de uma possível mudança linguística para alguns itens. Por outro lado, a configuração diatópica não confirma as divisões dialetais de Minas Gerais até então propostas, pelo menos no que se refere ao léxico.

Palavras-chave: projeto ALiB; EALMG; variação lexical; Minas Gerais.

Abstract: This article is a study regarding the lexical variations in the State of Minas Gerais, Brazil, and considers two synchronous delimitations, late 1970 s and early 2010 s. The aim is to discuss aspects of linguistic variation and change in real time and apparent time and the proposition of lexical areas in territory of Minas Gerais from the dialect divisions proposed by other scholars. To this end, two linguistic maps of the Draft of a Linguistic Atlas of Minas Gerais and data from the Linguistic Atlas of Brazil regarding variants of the concepts of bolinha de gude [mibs] and estilingue [slingshot] were selected. The data are analyzed quantitatively and qualitatively with graphics, tables, linguistic maps and interpretation of the results observed by correlating them to other studies. Among the findings, the importance of combining the real time study to the apparent time can be indicative of a possible language change for some items. On the other hand, the diatopic configuration does not confirm the dialect divisions established so far for Minas Gerais, at least as regards the lexicon.

Keywords: ALiB project; EALMG; lexical variation; Minas Gerais.

Recebido em 02 de outubro de 2015. Aprovado em 06 de janeiro de 2016.

\section{Introdução}

A língua falada em Minas Gerais apresenta-se como um traço peculiar do português brasileiro (PB) devido ao "sotaque" característico do mineiro. O modo de falar nessa região do país, em geral, é objeto de especulações populares e divulgado pela mídia de modo caricaturado, estando quase sempre atrelado à figura do "homem da roça", o caipira, 
e caracterizado pela pronúncia demorada, pelo uso de interjeições como "uai", expressões como "trem", "sô", pelo uso do diminutivo e redução dos vocábulos, tais como "pertim...", "quietim...", "estantim...".

Não apenas como fato curioso sobre o PB, o jeito mineiro de conversar há tempo é objeto de investigação de trabalhos de cunho dialetológico ou sociolinguístico. Vale salientar que dentre os trabalhos fundadores da Dialetologia brasileira encontra-se a obra de Teixeira (1938), que é um tratado sobre aspectos gramaticais e semântico-lexicais do português falado em Minas Gerais na primeira metade do século XX.

Outro fato que faz Minas Gerais ser um estado-chave para as pesquisas dialetológicas e sociolinguísticas é a relevância do Esboço de um Atlas Linguístico de Minas Gerais - o EALMG (RIBEIRO et al., 1977) - o segundo atlas linguístico de um estado brasileiro publicado, precedido apenas pelo Atlas Prévio dos Falares Baianos (ROSSI, 1963). O EALMG representa, para a Geolinguística brasileira, uma referência pelo caráter inaugural desse campo de estudo que, recentemente, tem o seu espaço consolidado no território nacional (ROMANO, 2013); e também porque foi inspiração para o surgimento de outros projetos de atlas linguísticos estaduais, por exemplo, o Atlas Linguístico do Estado de São Paulo - ALESP (CARUSO, 1983), e mesmo na elaboração de atlas já publicados como o Atlas Linguístico da Paraíba (ARAGÃO; BEZERRA de MENEZES, 1984), o Atlas Linguístico do Paraná (AGUILERA, 1994) e o Atlas Linguístico do Mato Grosso do Sul (OLIVEIRA, 2007). Inclusive, o EALMG exerceu influência direta na própria elaboração do Atlas Linguístico do Brasil - ALiB (CARDOSO et al., 2014) ${ }^{1}$.

Este artigo apresenta um estudo comparativo sobre a variação lexical em Minas Gerais a partir de dois corpora: (i) o corpus do ALiB, no que se refere às respostas de 92 mineiros para as questões 156, "coisinhas redondas de vidro que os meninos gostam de brincar" e 157, "o brinquedo feito de uma forquilha e duas tiras de borracha, que os meninos usam para matar passarinho?" do Questionário Semântico-Lexical do ALiB (COMITÊ NACIONAL DO PROJETO ALiB, 2001); e (ii) o corpus do EALMG (RIBEIRO et al., 1977), a partir da análise destas duas cartas linguísticas: 30 e 43, que se referem, respectivamente, à "bolinha de gude/bilosca" e "estilingue/atiradeira".

\footnotetext{
${ }^{1} \mathrm{O}$ Atlas Linguístico do Brasil (ALiB) é um projeto nacional de caráter interinstitucional cuja sede nacional encontra-se na Universidade Federal da Bahia, dirigido por um Comitê Nacional.
} 
Considerando os corpora selecionados, objetiva-se apresentar a distribuição diatópica das variantes lexicais para os referentes em pauta com vistas a discutir: (i) aspectos da variação e da mudança linguística em tempo real e tempo aparente (LABOV, 1996) em Minas Gerais; e (ii) a proposição de áreas lexicais no território mineiro, considerando as divisões estabelecidas por Zágari (1998) e Nascentes (1953).

\section{Aporte teórico}

Apresentam-se nesta seção os fundamentos teóricos que embasam o trabalho, abrangendo alguns aspectos teóricos e metodológicos da teoria da variação e mudança linguística (LABOV, 1996) e aspectos atinentes ao português falado em Minas Gerais, com foco para a descrição do EALMG e para a proposta de divisão dialetal de Zágari (1998).

\section{Princípios de variação e mudança linguística}

A variação e a mudança linguística são características inerentes a todas as línguas, ou seja, as línguas variam e, consequentemente, com o passar do tempo, mudam. A língua que se fala hoje não é inteiramente igual à que se falava há 25, 50 ou 100 anos atrás. Segundo Coseriu (1987, p. 76),

as palavras mudam continuamente; não só do ponto de vista fônico, mas também do ponto de vista semântico, uma palavra nunca é exatamente a mesma; diríamos melhor que uma palavra, considerada em dois momentos sucessivos de sua continuidade de emprego numa comunidade, não é $n i$ tout à fait une autre, ni tout à fait la même [nem totalmente uma outra, nem totalmente a mesma] [...] em nenhum momento se pode fixar um sistema estático concreto, porque em cada momento o sistema se quebra para constituirse e romper-se novamente - essa mudança contínua é, precisamente, o que chamamos a realidade da linguagem.

A variação linguística acontece por influências sociocomunicativas ou, até mesmo, por fatores linguísticos. Labov (1996) teve a preocupação de investigar as mudanças que as línguas sofrem com o passar de sua história. Segundo o pesquisador, é necessário partir do presente para o passado a fim de verificar o papel de fatores históricos e sociais que 
influenciam nesse processo. Para tanto, criou uma metodologia que possibilita verificar essa variação e mudança em tempo aparente e em tempo real.

O estudo em tempo aparente é um método mais imediato para verificar a mudança linguística, constitui-se em comparar a fala de pessoas mais idosas com a de pessoas mais jovens. A diferença entre elas poderá revelar casos de mudanças, ou seja, se o uso da variante inovadora for mais frequente entre os jovens, decrescendo em relação à faixa etária dos grupos mais idosos, tudo indica que se trata de uma situação de mudança em progresso. Nesse sentido, a fala de um indivíduo com 75 anos, no ano 2000, por exemplo, representaria um estado de língua de sessenta anos atrás, ou seja, 1940 (PAIVA; DUARTE, 2003).

Entretanto, Labov (1996) ressalta que o estudo em tempo aparente merece ser examinado com critério, pois as diferenças reveladas entre os grupos etários podem indicar a influência de outros fatores, como escolaridade, classe social, profissão, entre outros. Este método é útil quando não se dispõe de dados em tempo real.

O ideal para verificar as mudanças linguísticas é conjugar os resultados do tempo aparente aos obtidos em tempo real. O estudo em tempo real consiste na comparação de dois corpora coletados em recortes sincrônicos distintos. Desse modo, o pesquisador pode recorrer a diversos documentos históricos que retratem a língua falada no passado. Segundo Tarallo (1999, p. 71):

$\mathrm{O}$ atlas linguístico de uma comunidade pode, por exemplo, fornecer dados valiosíssimos para o estudo da variação fonológica, ou mesmo lexical. Além do atlas, textos escritos em prosa que potencialmente reflitam o vernáculo de um certo período de tempo poderão ser utilizados. Ressaltem-se aqui cartas de cunho pessoal, diários e textos teatrais que tenham visado, em seu momento de criação, a um retrato da fala de diferentes camadas da comunidade.

Tendo por base esses documentos e decorridos vinte anos ou mais, o pesquisador volta a mesma comunidade e coleta novos dados. Esse tipo de investigação pode ser feito de duas formas: i) o denominado 
estudo de tipo painel, quando se buscam necessariamente os mesmos informantes da primeira coleta, tarefa esta nem sempre possível devido a fatores diversos como falecimento, mudança e doença do informante, além de dificuldades circunstanciais; e ii) o estudo de tendência, quando se coleta uma nova amostra, guiando-se mais ou menos pelos mesmos procedimentos metodológicos da primeira pesquisa (não necessariamente os mesmos informantes), revelando as 'tendências' atuais da língua. Acerca dos dois tipos de estudo em tempo real, Paiva e Duarte (2003, p. 17) fazem as seguintes considerações:

Uma limitação inerente ao estudo do tipo painel é que os resultados não são conclusivos no que diz respeito aos mesmos fenômenos na comunidade de fala. Ao regravar sujeitos que já foram entrevistados em um momento anterior, o estudo de painel perde a aleatoriedade, não representando a comunidade de fala como um todo. O estudo tipo tendência, por sua vez, compara amostras aleatórias da mesma comunidade de fala [...] os falantes gravados podem ser considerados representativos da comunidade no momento da gravação [...]. Essa técnica nada diz sobre o comportamento linguístico do indivíduo, permite depreender a direcionalidade do sistema na comunidade linguística e verificar em que medida mudanças na configuração social de um grupo podem se refletir na propagação, na estabilização ou no recuo de processos de mudança.

Os resultados obtidos em tempo real e tempo aparente possibilitarão dizer com propriedade se determinada variante linguística apresenta uma variação estável ou se trata de uma mudança em progresso.

Englobando essas duas perspectivas de Labov (1996), este trabalho é um estudo em tempo aparente à medida que se considera a faixa etária dos informantes do ALiB como uma importante variável extralinguística no processo de variação e mudança linguística em Minas Gerais. Trata-se, ainda, de um estudo em tempo real (estudo tendência), pelo fato de se comparar dois momentos sincrônicos distintos: década de 1970, com base nos dados do EALMG; e início da segunda década do século XXI, a partir dos dados do ALiB. 


\section{A língua portuguesa falada em Minas Gerais}

Teixeira (1938, p. 12) já anotara que "a fala do mineiro é calma e sossegada" e que nela "impera, mais do que em qualquer outra, a lei do menor esforço, criando através das alterações fonéticas, um timbre de notas aveludadas, que traduz o temperamento brando e suave, gerado nos longos anos de pacíficas atividades agrícolas e pastoris".

Esses e outros aspectos peculiares da língua portuguesa falada em Minas Gerais, associados a aspectos sócio-históricos, fazem dela um interessante objeto de investigação que já fora documentado sob o ponto de vista geolinguístico, pelo menos parcialmente, no EALMG (RIBEIRO et al., 1977).

Todavia, apesar de Minas Gerais ter sido o segundo estado em ordem cronológica a ter seu atlas linguístico publicado, os trabalhos geolinguísticos nesse estado ainda estão latentes. Observa-se, contudo, o desenvolvimento da Dialetologia e de trabalhos de cunho sociolinguístico de forma muito profícua, resultando não apenas em livros organizados como também em artigos publicados em periódicos especializados e monografias acadêmicas.

Considerando os trabalhos mais recentes, nota-se a existência de sete obras de referência que reúnem pesquisas acerca da língua portuguesa em Minas Gerais: Cohen e Ramos (2002), Dogliani e Cohen (2011), Viegas (2011), os Anais do I Encontro sobre Diversidade Linguística de Minas Gerais - DIVERMINAS (2011), Amaral (2013), Viegas (2013) e Ramos e Coelho (2013). Observa-se, porém, que nas sete obras supramencionadas há certa predominância, ou preferência dos autores, por aspectos atinentes a temas gramaticais e, em menor escala, estudos acerca de aspectos semântico-lexicais, que, em geral, estão descritos em trabalhos monográficos específicos de determinada região do estado, com vistas à constituição de glossários.

Em consonância às ideias de Rocha (2012, p. 79), esses trabalhos "contribuem e contribuirão, sem dúvida, para a identificação de áreas dialetais presentes no estado, mas em médio e em longo prazos". Por ora, para uma visão ampla sobre a distribuição diatópica do léxico em Minas Gerais têm-se as cartas linguísticas do EALMG e os dados coletados pela equipe do Projeto ALiB em 23 localidades mineiras. 


\section{O EALMG e os falares mineiros}

O EALMG foi o segundo atlas linguístico de um estado brasileiro a ser publicado e foi projetado para ser divulgado em quatro volumes, sendo, contudo, somente o primeiro divulgado em 1977. O EALMG teve um questionário composto de 415 questões aplicado por meio da pesquisa in loco em 116 pontos linguísticos. Seu primeiro e único volume apresenta os resultados da pesquisa realizada e contém 73 cartas linguísticas, das quais 45 são onomasiológicas de caráter lexical e léxico-fonético e 28 cartas são de isófonas e de isoléxicas.

Nesse atlas, não houve o controle sistemático das variáveis sociais, pois os informantes poderiam ser homens ou mulheres com faixa etária entre 30 e 50 anos, preferencialmente, analfabetos ou com nível máximo de escolaridade até a quarta série do primeiro grau. Entretanto, conforme se verifica na apresentação do atlas, quase todos os informantes são homens, num ou noutro ponto foi entrevistada uma informante do sexo feminino, mantendo-se, pois, os critérios da Dialetologia tradicional ou monodimensional (THUN, 1998). Apesar de o perfil do informante, na prática, seguir o critério tradicional, vale notar que o EALMG atingiu grandes, médias e pequenas cidades, além dos lugares mais afastados do sertão mineiro.

A partir das cartas linguísticas do EALMG, Zágari (1998) formalizou a clássica divisão dialetal de Minas Gerais estabelecendo três grandes áreas dialetais, que segundo ele, "a ocupação dos espaços imensos de Minas Gerais, através de três vias a que a geografia e a história deram vida, reforça e ajuda a explicar a existência de três falares no Estado" (p. 33-34), e utilizando-se da nomenclatura de Nascentes (1953), divide-as em (Figura 1):

- O falar baiano, no norte do estado, onde há a predominância do abaixamento de vogais médias pretônicas;

- O falar paulista, localizado no Triângulo Mineiro e no sul do estado, cujo traço fonético característico é a presença do $/ \mathrm{r} /$ retroflexo;

- O falar mineiro, "preso entre essas duas áreas que, não possuindo nenhuma das características enumeradas anteriormente, desfaz constantemente os ditongos [aj], [ej] e [ow] quando não finais e faz surgirem outros quando finais e antecedidos de sibilante" (ZÁGARI, 1998, p. 34). 


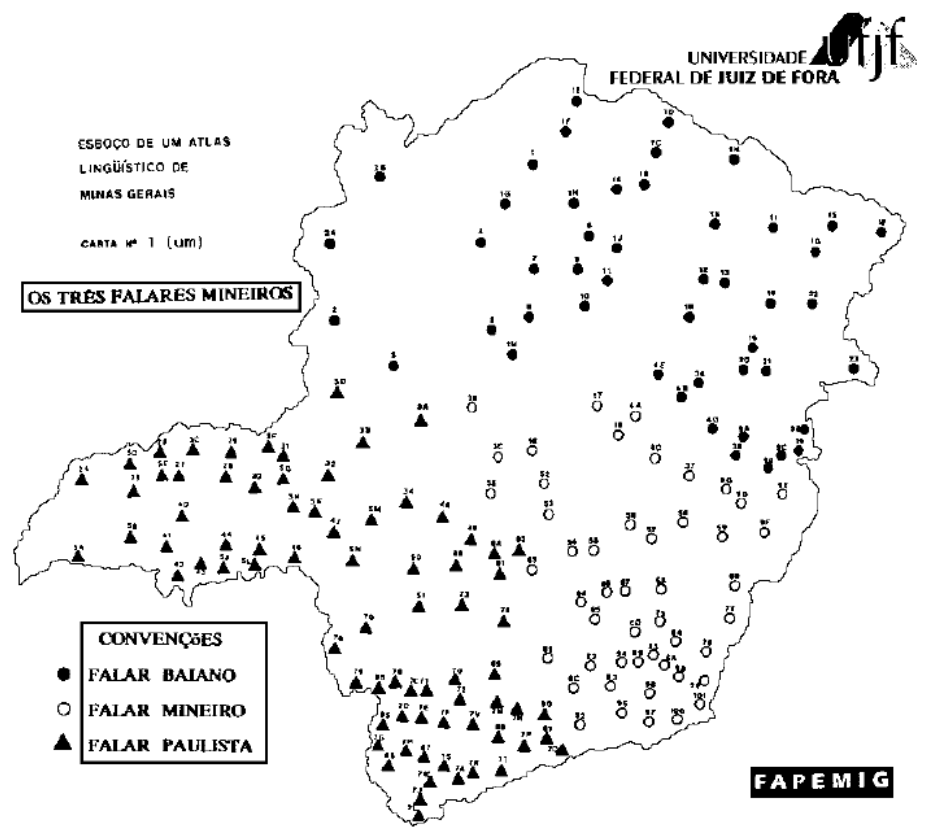

Figura 1 - Divisão dialetal de Minas Gerais proposta por Zágari (1998)

Fonte: Zágari (1998, p. 46)

Ao fazerem uma releitura da proposta de Zágari (1998) pautandose em aspectos fonéticos de nove localidades da rede de pontos do ALiB, Rocha e Antunes (2014) concluem que

os critérios fonéticos usados por Zágari (1998) para propor a tripartição dialetal do estado, ainda que apresentem algumas contradições, mostram tendências de pronúncia que continuam ocorrendo no estado [...]. A proposta de dividir o português de Minas Gerais em três regiões ou subfalares continua tendo respaldo, mesmo nos dados aqui analisados - que são atuais -, mas não se pode pensar em uma divisão estanque (p. 109-110).

Por outro lado, Rocha e Ramos (2010), ao fazerem comentários históricos sobre a Dialetologia em Minas Gerais, atestam que "a 
tripartição sustenta-se sobre os dados fonéticos, não sobre os lexicais" (p. 77), considerações estas que Rocha (2012) também concorda ao trazer algumas notas sobre o léxico para as brincadeiras infantis no estado, pois, segundo a autora, "viu-se que as cartas lexicais presentes no ALEMiG ( sic) sustentam apenas parcialmente a tripartição dialetal proposta por Zágari (1998), a qual se sustenta, de forma consistente, nas cartas fonéticas da referida obra" (p. 86). Contudo, na ocasião da conclusão de Rocha (2012), a equipe de pesquisadores do ALiB ainda não havia terminado a coleta de dados em todos os pontos de Minas Gerais.

Todavia, o prognóstico de Rocha e Ramos (2010) e de Rocha (2012) sobre a não-validação da proposta de Zágari (1998) no que se refere ao léxico de Minas Gerais merece análise mais cuidadosa, agora que a equipe do ALiB já concluiu a coleta de dados em todo o estado e há a viabilidade de cartografia sistemática das variantes lexicais, embora se façam pertinentes os apontamentos de Rocha (2012, p. 84-85):

O que se quer discutir é a (in)viabilidade de se usar o ALEMiG em cotejo com os novos dados coletados pela equipe do $\mathrm{ALiB}$ a fim de se fazer um estudo diacrônico a respeito do uso de itens lexicais relacionados a brincadeiras infantis. Por questões aparentemente óbvias (a crescente urbanização do estado de Minas desde a década de setenta, a inserção das crianças no mundo das brincadeiras digitais observada nos últimos anos, as mudanças quanto à ocupação das ruas e espaços públicos para brincadeiras de crianças em grupo, a diminuição do número de filhos por família etc.), é plausível a hipótese de que os itens lexicais relacionados a brincadeiras infantis venham sofrendo não só nas variedades mineiras do português, mas também nas demais - notáveis mudanças. A questão que aqui se coloca é: em que medida o cotejo dos dados do ALEMiG com os dados do ALiB permitem detectar essas possíveis mudanças?

Essas indagações motivam a discussão de tais aspectos a partir dos corpora selecionados para este trabalho, contribuindo para a descrição da área semântica Jogos e Diversões Infantis no território mineiro. O estudo em tempo aparente conjugado ao estudo em tempo real poderá indicar a viabilidade do cotejo de dados do EALMG em relação ao ALiB, dando 
pistas do processo de mudança linguística que poderá estar em progresso ou concluída, pelo menos, nos aspectos lexicais aqui discutidos, sendo os fatos sócio-históricos apontados por Rocha (2012) uma das causas que propiciaram essa possível mudança.

Ademais, essa área semântica do QSL do ALiB já foi estudada por Ribeiro (2012), no que se refere ao falar baiano proposto por Nascentes (1953) e por Portilho (2013), no falar Amazônico. Mais especificamente, a questão 156 (bolinha de gude) do QSL fora estudada por Romano (2015) na área geográfica do falar sulista.

Minas Gerais, na divisão de Nascentes (1953), está localizado na confluência de quatro falares (Figura 2): o sulista (no sul e Triângulo Mineiro), o baiano (no norte do estado), o fluminense (na região leste) e o propriamente mineiro (região de Belo Horizonte e adjacências).

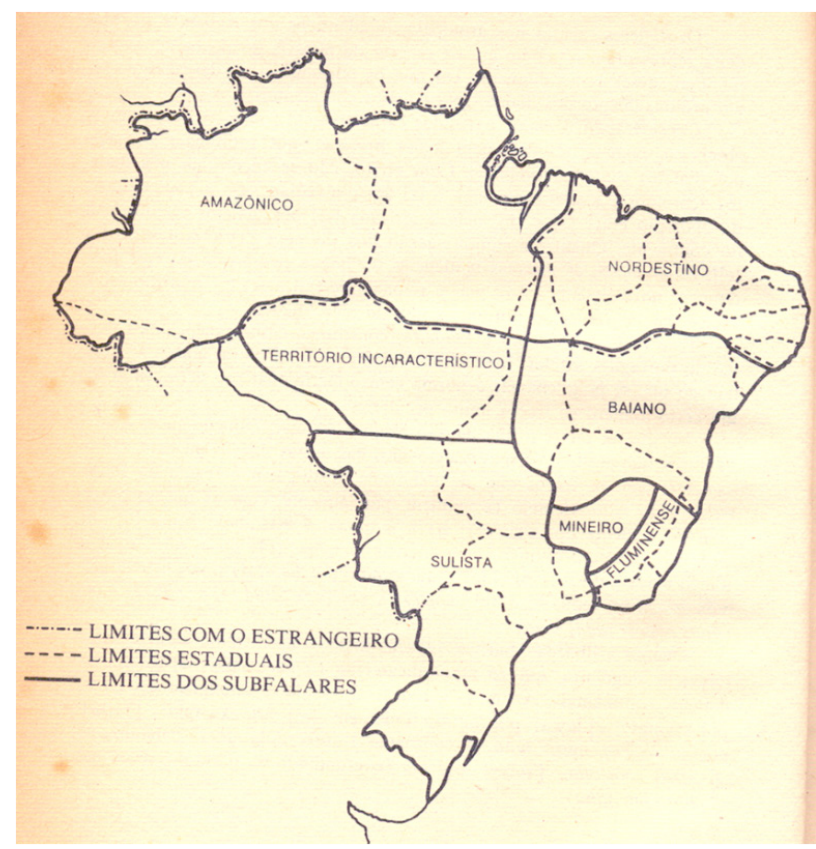

Figura 2 - Divisão dialetal de Nascentes (1953) Fonte: Nascentes (1953)

Com base nesse fato, neste estudo, busca-se contribuir para a descrição do léxico mineiro. Essa iniciativa se apresenta como a primeira 
abordagem sistemática para o tratamento da variação diatópica mais ampla em Minas Gerais com dados atuais do PB, com vistas a cooperar para o desenvolvimento da Geolinguística mineira que, de certa forma, encontra-se "adormecida".

\section{Materiais e métodos}

A equipe do Projeto ALiB iniciou a coleta de dados em Minas Gerais em setembro de 2006, em Belo Horizonte (ponto 138), e finalizou a coleta em junho de 2013, em São João del Rei (ponto 145). Esse período de sete anos para o levantamento de dados se deu pela participação de duas equipes regionais do ALiB: pela equipe do Paraná e pela equipe da Bahia

Nesse período foram coletados os dados em 23 localidades uniformemente distribuídas pelo território, contemplando médias e grandes cidades. Os critérios de seleção dessas localidades não foram aleatórios, conforme se observa em Cardoso et al. (2014a), e cada localidade está identificada por números começando no ponto 127 e terminando no 149, cuja identificação se apresenta no Quadro 1.

Em cada localidade, foram entrevistados quatro informantes (dois homens e duas mulheres), naturais da região linguística, cujo nível máximo de escolaridade era o ensino fundamental completo. $\mathrm{Na}$ capital, Belo Horizonte, além desses quatro informantes, foram acrescidos quatro informantes de nível superior completo, cujos dados não estão sendo utilizados neste trabalho devido aos objetivos aqui propostos.

Visando a coletar a variação linguística em tempo aparente, os quatro informantes de cada localidade compreendem duas faixas etárias: faixa I, de 18 a 30 anos; e faixa II, de 50 a 65 anos, distribuídos segundo o sexo, sendo um representativo de cada célula social.

No Quadro 2, encontra-se o perfil e a quantidade dos informantes considerados para este artigo. 
Quadro 1 - Identificação da rede de pontos do ALiB em Minas Gerais

\begin{tabular}{|c|l|}
\hline $\mathbf{N}^{\mathbf{0}}$ do Ponto & Nome da localidade \\
\hline 127 & Januária \\
\hline 128 & Janaúba \\
\hline 129 & Pedra Azul \\
\hline 130 & Unaí \\
\hline 131 & Montes Claros \\
\hline 132 & Pirapora \\
\hline 133 & Teófilo Otoni \\
\hline 134 & Diamantina \\
\hline 135 & Uberlândia \\
\hline 136 & Patos de Minas \\
\hline 137 & Campina Verde \\
\hline 138 & Belo Horizonte \\
\hline 139 & Ipatinga \\
\hline 140 & Passos \\
\hline 141 & Formiga \\
\hline 142 & Ouro Oreto \\
\hline 143 & Viçosa \\
\hline 144 & Lavras \\
\hline 145 & São João del Rei \\
\hline 146 & Muriaé \\
\hline 147 & Poços de Caldas \\
\hline 148 & Juiz de Fora \\
\hline 149 & Itajubá \\
\hline & \\
\hline
\end{tabular}

Fonte: Cardoso et al. (2013, p. 132)

Quadro 2 - Distribuição dos informantes conforme as variáveis sexo e faixa etária

\begin{tabular}{|l|l|l|}
\hline \multirow{2}{*}{ Homem } & Faixa I & 23 \\
\cline { 2 - 3 } & Faixa II & 23 \\
\hline \multirow{2}{*}{ Mulher } & Faixa I & 23 \\
\cline { 2 - 3 } & Faixa II & 23 \\
\hline TOTAL & 92 \\
\hline
\end{tabular}

Fonte: Cardoso et al. (2014a) 
Desse modo, observa-se que o ALiB se enquadra nas tendências atuais da Dialetologia mundial, conjugando variáveis sociais à dimensão diatópica, tratando-se, pois, de um atlas urbano e pluridimensional. Essa abordagem da Dialetologia pluridimensional apresenta um tratamento especial para a variação linguística, de forma "que corrige as deficiências da geolinguística tradicional e acrescenta à sociolinguística uma importância maior ao valor do espaço no debate sobre a variação: o conceito das interrelações no espaço" (MARGOTTI, no prelo).

No entanto, o caráter pluridimensional do ALiB não reside somente no perfil do informante, mas também na própria estruturação dos instrumentos de coleta. Os questionários 2001 (COMITÊ NACIONAL DO PROJETO $\mathrm{ALiB}, 2001)$ compõem-se, basicamente, de três tipos de questionário, o Fonético-Fonológico (QFF), o Semântico Lexical (QSL) e o Morfossintático (QMS), além de questões de prosódia, metalinguísticas, pragmática, texto para leitura, ficha do informante e temas para discursos semidirigidos. O QSL divide-se em 14 áreas semânticas e compõe-se de 202 questões. Aárea semântica Jogos e Diversões Infantis é composta por 13 questões acerca do universo ludológico, iniciando-se pela pergunta 155 (cambalhota) até a 167 (amarelinha). Selecionaram-se, para este estudo, as respostas dos mineiros para as questões 156 (bolinha de gude) e 157 (estilingue).

Já o EALMG é um atlas de caráter monodimensional, pois não apresenta em sua cartografia aspectos que ultrapassem os limites de análise diatópica, embora se reconheça, na apresentação do atlas, as intenções de adentrar aos "veios sociolinguísticos" (CARDOSO, 2010).

As questões selecionadas para este artigo possibilitam um estudo comparativo, pois tratam de referentes cujas variantes lexicais estão documentadas em cartas linguísticas do EALMG. Selecionaram-se, portanto, as duas cartas principais que apresentam a distribuição diatópica das variantes que recobrem os conceitos das questões, ignorando as cartas decorrentes de desdobramentos léxico-fonéticos, além das duas cartas principais (30 bolinha de gude e 43 estilingue/atiradeira). Na próxima seção, são apresentadas a descrição e a análise dos resultados comparando ambos os corpora.

\section{Análise dos dados}

Esta seção visa a apresentar a análise dos corpora selecionados. Para tanto, divide-se em duas subseções: a que trata dos dados para bolinha de gude e a que apresenta os resultados para estilingue. 


\section{Bolinha de gude e suas variantes}

Para a questão 156 ("como se chamam as coisinhas redondas de vidro com que os meninos gostam de brincar?"), foram documentados 113 registros distribuídos em 15 itens lexicais: bolinha de gude (63 ocorrências), biloca (9), birosca (7), bola de gude (7), bolinha de vidro (6), china (4), boleba (4), gude (4), bolinha de crique (2), bolinha (2); e como ocorrências únicas: bilisco, biroquê, bolinha de crica, bilosca e pedrinha de gude.

Como se observa, foram obtidas lexias simples e lexias compostas (gude/bola de gude), além de variantes fonéticas e morfológicas de um mesmo item. A partir das equivalências de formas consideradas morfofonêmicas ${ }^{2}$ e itens que apresentam formas compostas, observa-se no Gráfico 1 a distribuição percentual dessas variantes.

Gráfico 1 - Produtividade das variantes lexicais para questão 156 em MG

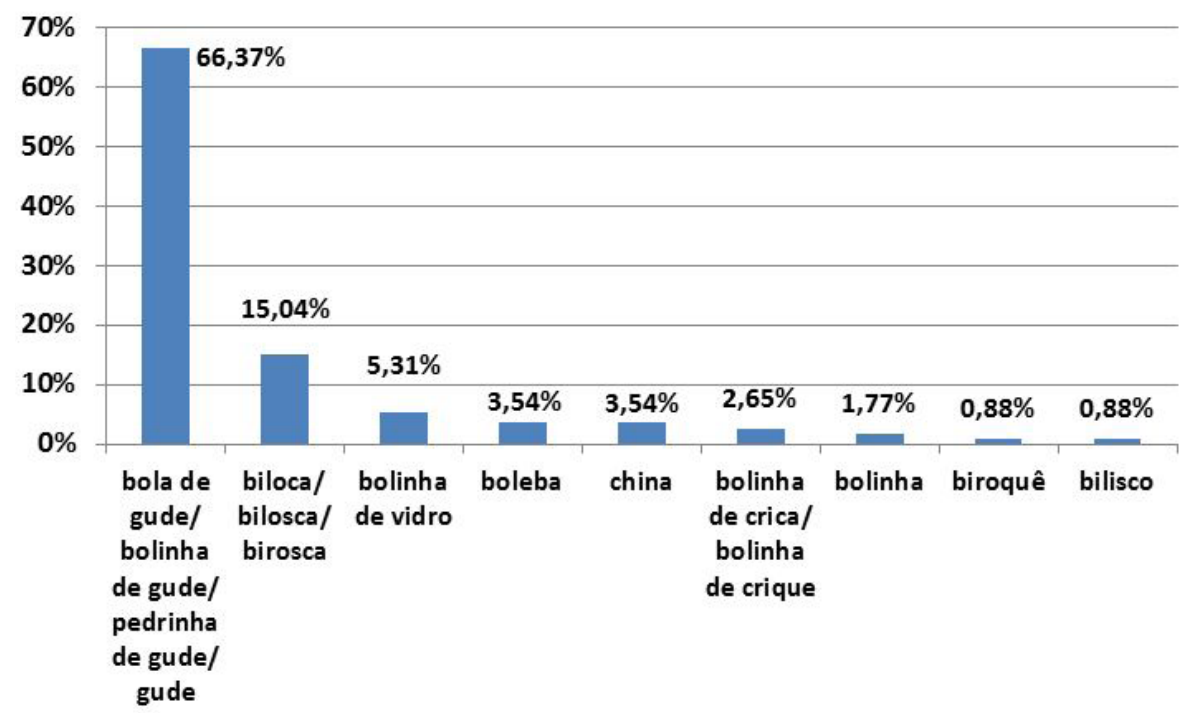

Fonte: Banco de dados do ALiB (2015)

\footnotetext{
${ }^{2}$ Carreter (2008, p. 281), acerca das variantes morfofonêmicas, afirma que "los fonólogos han propuesto este término para designar 'la idea compleja de todos los miembros (dos o más) de una alternancia. Así, en la alternancia que se produce en las formas alemanas geben-gab-gib, las vocales $e$, a, e (llamadas alternantes) constituyen uno morfofonema"
} 
A variante mais produtiva no corpus é bola/bolinha de gude e formas equivalentes em aproximadamente $67 \%$ das respostas, seguida de biloca $(15,04 \%)^{3} \mathrm{e}$, em menor produtividade, os demais itens lexicais. Na Figura 3, encontra-se a distribuição diatópica desses itens, estando bola/bolinha de gude presente em todos os pontos linguísticos, ao passo que os de menor produtividade encontram-se em localidades específicas.
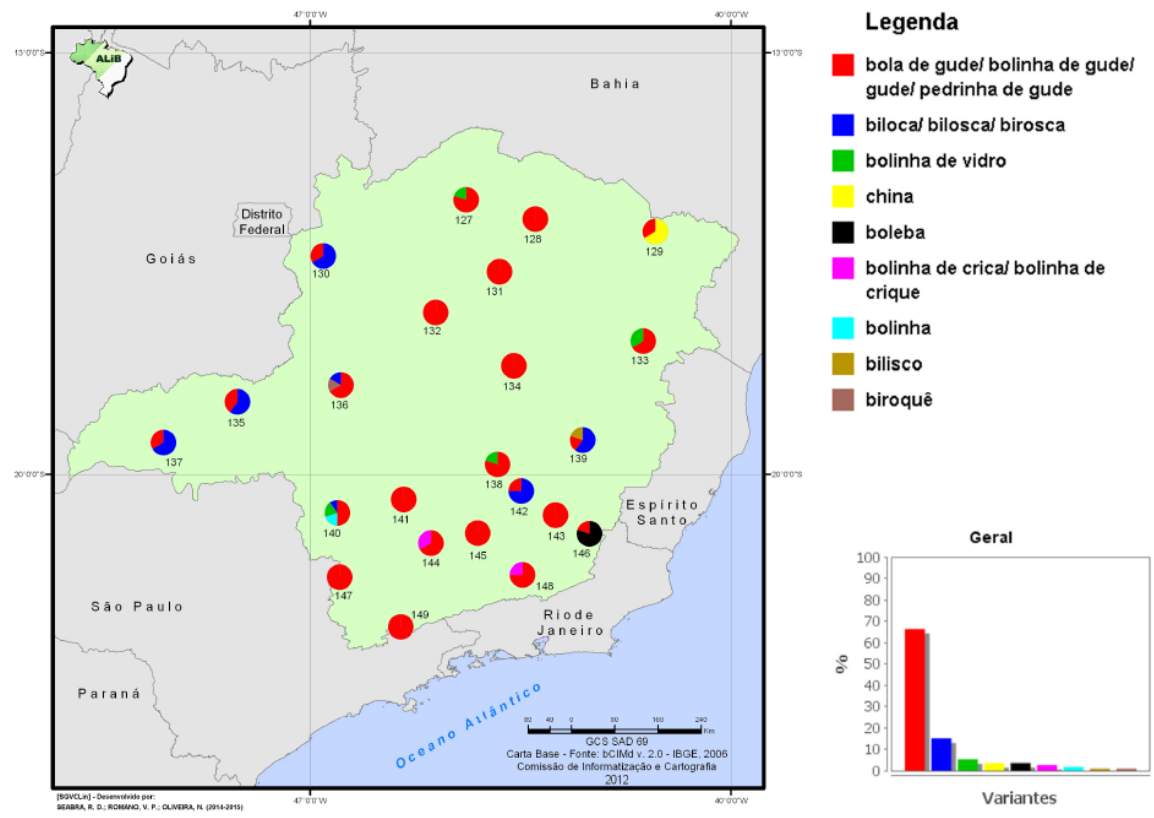

Figura 3 - Distribuição diatópica das variantes lexicais para a questão 156 do QSL $^{4}$ Fonte: Banco de dados do ALiB (2015)

\footnotetext{
${ }^{3}$ Para tratar das formas agrupadas, ao longo do texto, opta-se pelo uso da variante mais produtiva. Assim, ao usar o vocábulo biloca, necessariamente, nos referimos às suas variantes morfofonêmicas, bilosca e birosca.

${ }^{4}$ As cartas linguísticas e os dados quantitativos apresentados neste estudo, no que se refere aos dados do ALiB, foram obtidos a partir do uso da ferramenta SGVCLin. Mais informações sobre esse software podem ser encontradas em Romano, Seabra e Oliveira (2014) e no website: http://sgvclin.altervista.org/
} 
Biloca e variantes apresentam-se de forma significativa em duas localidades do Triângulo Mineiro: pontos 135 em Uberlândia (60\%) e 137 em Campina Verde (66,67\%) e, em menor produtividade, em Patos de Minas (ponto 136 - 16,67\%). Essas variantes também figuram significativamente em um município do noroeste mineiro: ponto $130 \mathrm{em}$ Unaí $(66,67 \%)$ e na região metropolitana, em Ipatinga (ponto $139-60 \%$ ) e Ouro Preto (ponto $142-75 \%$ ).

A forma bolinha de vidro ocorre em quatro localidades esparsamente distribuídas pelo estado. No norte mineiro, apresenta-se em Januária - ponto 127 (20\%). No nordeste, ocorre em Teófilo Otoni (ponto 133 ) com significativa representatividade $(66,67 \%)$. No centro do estado, bolinha de vidro foi documentada na capital (ponto $138-20 \%$ ) e, no sul de Minas, encontra-se em Passos (ponto 140 - 20\%).

No corpus, observa-se a presença de duas variantes: china, em Pedra Azul (ponto 129), no nordeste do estado, em que a ocorrência do item é categórica como primeira resposta de todos os informantes $(66,67 \%-4$ ocorrências) dessa localidade, e a variante boleba, que ocorre na fala dos quatro informantes de Muriaé (ponto 146), localizada na região da Zona da Mata.

Ainda na Zona da Mata, observa-se a presença de bolinha de crica/crique em Juiz de Fora (ponto 148) com $25 \%$ das respostas (uma ocorrência) e na fala de dois informantes de Lavras (ponto 144), na região sul do estado, representando $33,33 \%$ das respostas válidas nessa localidade.

O item bolinha apresenta-se unicamente em Passos (ponto 140), também no sul, com duas ocorrências (20\%) e, como hápax legomena, a variante bilisco ocorre em Ipatinga (ponto 139) e o item biroquê, em Patos de Minas (136).

Considerando o universo das variantes distribuídas segundo a variável faixa etária, obtém-se o panorama ilustrado no Gráfico 2.

Observa-se que tanto entre os informantes da faixa etária I (18 a 30 anos) quanto entre os da faixa etária II (50 a 65 anos), a variante mais produtiva é bola/bolinha de gude, mas entre os informantes mais jovens o item é mais produtivo. Nota-se, contudo, certa diferença entre as duas gerações no que se refere a quatro itens lexicais, bolinha de vidro, bolinha de crica/crique, biroquê e bilisco. Essas variantes ocorrem, exclusivamente, entre os informantes da faixa etária II, revelando a variação diageracional. Os relatos dos informantes ratificam que essas 
formas não são usadas com frequência na atualidade, estando preservadas apenas na fala de pessoas de gerações mais velhas ${ }^{5}$.

Gráfico 2 - Produtividade das variantes para a questão 156 segundo a variável faixa etária

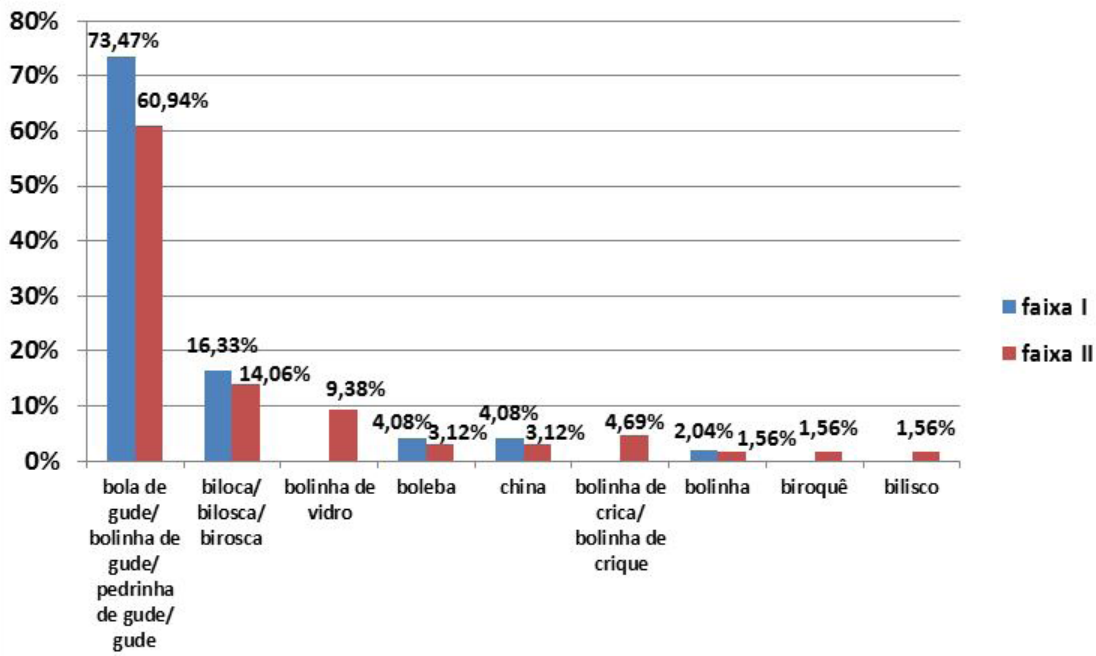

Fonte: Banco de dados do ALiB (2015)

INF.- Antigamente era bolinha de vidro, hoje é bolinha de gude. ${ }^{6}$

INF.- Bolinha de gude.

INQ.- Já ouviu outro nome?

INF.- Bolinha de crique.

INQ.- Qual é mais comum?

INF.- Na época era bolinha de crique, depois quando foi ficano evoluino, tornou-se bolinha de gude. ${ }^{7}$

${ }^{5}$ Os trechos cotejados fazem parte do banco de dados do ALiB e referem-se às transcrições grafemáticas dos inquéritos, que seguem normas previamente estabelecidas. As siglas INF e INQ referem-se, respectivamente, aos turnos do informante e do inquiridor (entrevistador).

${ }^{6}$ Informante 3, homem da faixa etária II de Teófilo Otoni (ponto 133).

${ }^{7}$ Informante 3 , homem da faixa etária II de Lavras (ponto 144). 
Biroquê e bilisco são ocorrências únicas que figuram nas respostas das informantes de número 4 (mulher, faixa etária II), de Patos de Minas (ponto 136) e de Ipatinga (139), respectivamente. Observa-se, assim, que a variação linguística em tempo aparente evidencia uma possível mudança em progresso, pois o uso de biroquê, bolinha de vidro, bolinha de crique e bilisco ocorrem apenas nas fala de pessoas da faixa etária II, não sendo empregada na fala dos informantes jovens, ao passo que esses, para denominar o referente, preferencialmente, optam pela variante inovadora ou padrão, bolinha de gude.

Quanto à variação e mudança linguística em tempo real, observando-se a carta linguística 30 do EALMG (Figura 4), verifica-se uma diferença entre os dois corpora.

Adaptando a carta do EALMG com linhas virtuais que delimitam as áreas de ocorrência de bolinha de vidro no corpus da década de 1970, verifica-se uma ampla distribuição do item em sentido transversal, partindo do ponto 44 (Veríssimo), localizado no Triângulo Mineiro, até o ponto 58 (Caratinga), na mesorregião do Vale do Rio Doce, de onde desce até o ponto 110 (Além Paraíba), na Zona da Mata. Outra linha de isoléxica está no sentido leste-oeste a partir do ponto 3 (João Pinheiro) ao 23 (Nanuque), na mesorregião do Vale do Mucuri. Havia, portanto, na década de 1970, uma maior distribuição diatópica da variante bolinha de vidro no território mineiro, ao passo que na atualidade a produtividade diminuiu sua área de abrangência, restringindo-se à fala de pessoas de mais idade (faixa etária II), ratificando a preferência dos informantes pela variante bolinha de gude, embora já estivesse significativamente distribuída pelo território mineiro.

É interessante observar que, no EALMG, a variante boleba ocorreu apenas uma vez e é apresentada como nota, com ursa e risca; estas duas últimas não registradas nos dados do ALiB. No referido atlas, boleba foi documentada apenas em Muriaé (ponto 76), que no ALiB é o ponto 146. Conforme se observa na Figura 3, essa variante ainda persiste no vocabulário dos muriaenses, pois foi a primeira resposta dos quatro informantes dessa localidade. Os dados em tempo real confirmam essa particularidade do léxico nesse local que, possivelmente, recebe influência do denominado falar fluminense, de Antenor Nascentes, ou faz parte dele.

Essa hipótese se justifica pelo fato de que o trabalho de Ribeiro (2012), que também pauta-se no corpus dos dados do ALiB, ao tratar do 
falar baiano (NASCENTES, 1953), apresenta o item boleba em duas localidades capixabas, pontos 188 (Barra de São Francisco) e 189 (São Mateus), no extremo norte do Espírito Santo, ou seja, nas adjacências do falar baiano.

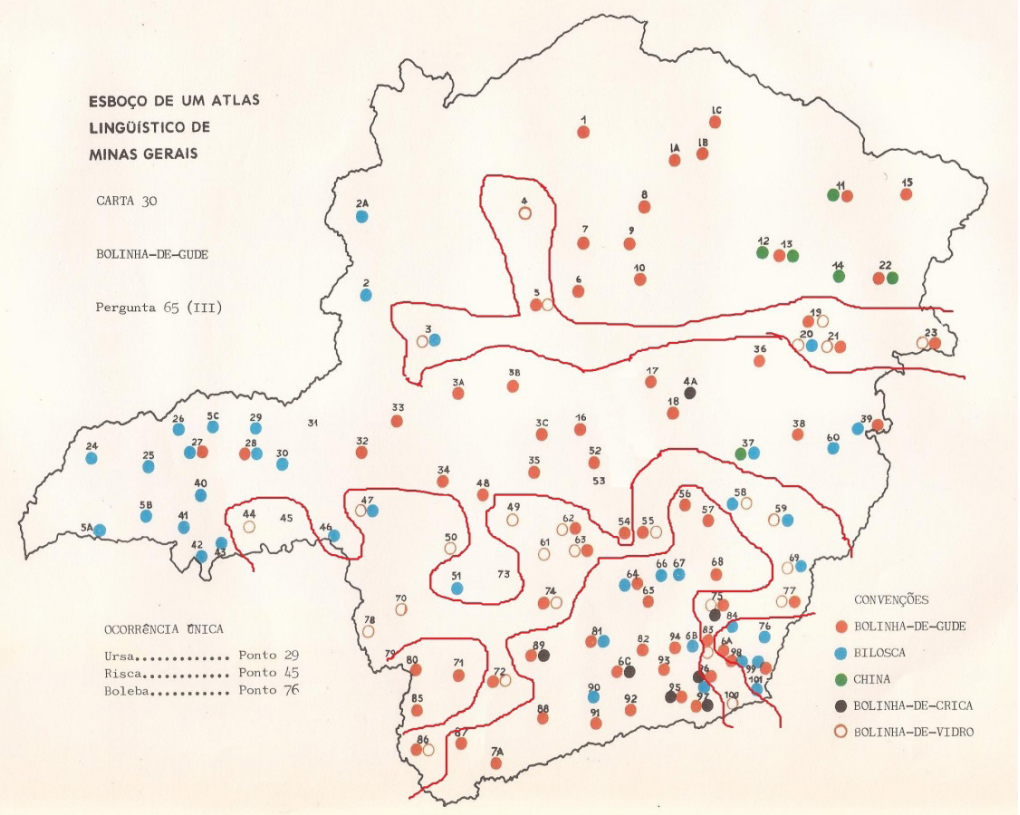

Figura 4 - Carta linguística 30 do EALMG: isoléxica de bolinha de gude Fonte: Ribeiro et al. (1977) - adaptada

Dada a localização de Muriaé (próxima a fronteira de MG com RJ e ES), pode-se inferir uma possível influência do falar fluminense, pois na divisão de Nascentes (1953) (Figura 2), a parte leste de Minas Gerais está na área do denominado falar fluminense, o que de certo modo, pelos dados aqui analisados, pode ratificar a divisão.

Ademais, cabe observar que o item não se encontra documentado na área correspondente ao falar amazônico, área linguística estudada por Portilho (2013), cujo corpus perfaz 20 localidades da região Norte do Brasil, totalizando 100 informantes. Boleba também não se encontra na área do denominado falar sulista (ROMANO, 2015), cujos dados contemplam 472 informantes de 118 
municípios brasileiros distribuídos por 10 unidades federativas (RS, SC, PR, SP, MS, parte do Triângulo Mineiro e sul de Minas, e parte do território de GO e MT), levando a crer que este item possa ser característico do falar fluminense que, por ora, ainda não se encontra suficientemente estudado nos dados do ALiB sob a perspectiva do léxico. Ratifica-se a necessidade de mais estudos nessa região de Minas com vistas a confirmar ou não essa hipótese.

A carta 30 do EALMG possibilita ainda o traçado de outras linhas de isoléxicas, conforme se observa na Figura 5. Observando-se a carta adaptada, nota-se que bilosca (linha azul), distribui-se em duas áreas: uma no Triângulo Mineiro, subindo até o ponto 2A (Unaí), e outra que contempla uma faixa do sul de Minas, ponto 90 - Andrelândia - até o ponto 20, Poté, no Vale do Mucuri.

Nesse caso, não cabe atrelar a ocorrência de bilosca ao denominado falar paulista, proposto por Zágari (1998), uma vez que o item se apresenta em outras áreas além do Triângulo Mineiro e sul de Minas Gerais. No estudo de Romano (2015), essa variante encontra-se distribuída também pelo noroeste paulista e oeste desse estado, além de abranger o sudoeste goiano, conforme se observa na Figura 6, que é um recorte de uma carta linguística constante do trabalho do autor. Dados sócio-históricos discutidos por Romano (2015) confirmam que foram os mineiros que deixaram traços no vocabulário dessa região paulista, e não o contrário.

Ou seja, comparando-se a Figura 5 com a Figura 6, observa-se que a isoléxica de bilosca, nos dados do ALiB, vai além dos limites políticos do estado de Minas Gerais, revelando uma área lexical de influência mineira, mas não se encaixando na tripartição de Zágari (1998).

Outra isoléxica encontrada na Carta 30 do EALMG (Figura 5) é a de bolinha de crica/crique (linha preta), que ocorre a partir do ponto 97 (Mar de Espanha, na Zona da Mata), adentrando-se o interior do estado até Lavras (ponto 89), sul de Minas. Há ainda no EALMG a ocorrência isolada dessa variante em Viçosa, ponto 75 (Zona da Mata).

A quarta e última isoléxica é a da variante china, no Vale do Mucuri, pontos 11 (Medina), 12 (Virgem da Lapa), 13 (Araçuaí), 14 (Padre Paraíso) e 22 (Águas Formosas), além de ocorrência fora dessa área em uma localidade, ponto 37 (Açucena, no Vale do Rio Doce). As áreas lexicais reveladas por essas linhas apresentam semelhanças com as que os dados do ALiB evidenciam (Figura 7). 


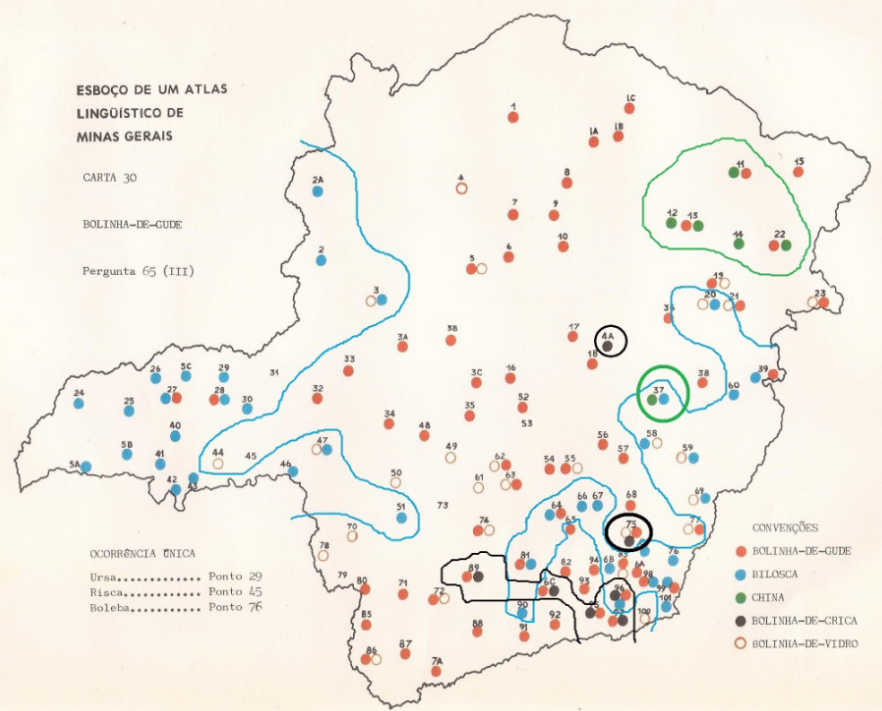

Figura 5 - Carta linguística 30 do EALMG: isoléxicas de bilosca, bolinha de crica e china

Fonte: Ribeiro et al. (1977) - adaptada

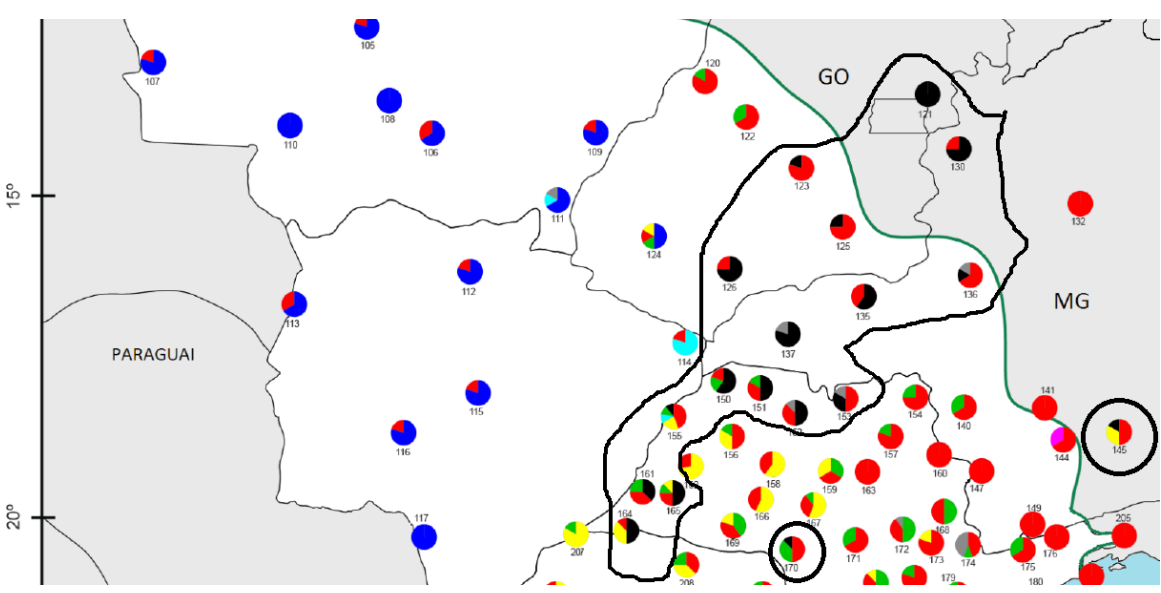

Figura 6 - Isoléxica da variante bilosca na área do falar sulista Fonte: Carta 3 - Fragmento, adaptado por Romano (2015) 


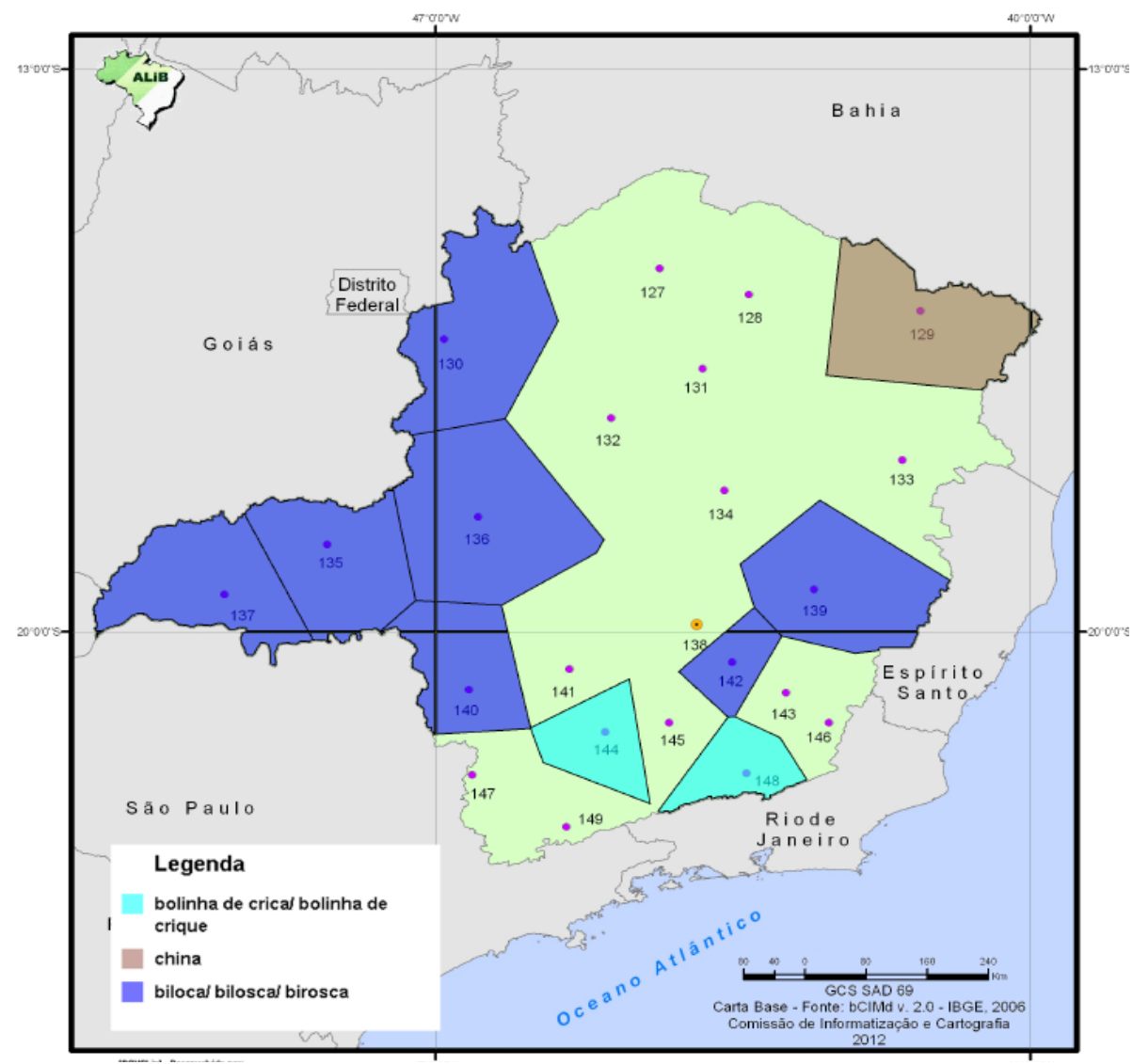

Figura 7 - Áreas lexicais de biloca/bilosca/birosca, bolinha de crica/crique e china nos dados do ALiB.

Fonte: Banco de dados do ALiB (2015)

Os dados atuais confirmam parcialmente a distribuição diatópica das isoléxicas encontradas no EALMG, embora a rede de pontos do ALiB seja menos densa devido aos aspectos metodológicos do atlas nacional.

Atualmente, a área de bilosca e variantes morfofonêmicas ainda se distribui em duas regiões do estado, separadas uma da outra, partindo do Triângulo Mineiro, atingindo Passos no sul do estado (ponto 140), e seguindo em direção ao noroeste de Minas, Unaí (ponto 130), assim como a isoléxica encontrada no EALMG. No leste mineiro, localiza-se 
em Ipatinga (Vale do Rio Doce) e Ouro Preto (região metropolitana). No EALMG, contudo, essa segunda área apresenta-se de forma mais ampla (Figura 5). Complementando essa distribuição com os resultados obtidos por Romano (2015), observa-se que bilosca adentra também o estado de São Paulo e de Goiás (Figura 6).

Bolinha de crica/crique encontra-se na mesma região do estado, confirmando os dados do EALMG, Zona da Mata e Sul de Minas (pontos 148 - Juiz de Fora e 144 - Lavras), porém, em Romano (2015), o item é registrado significativamente em duas localidades catarinenses (pontos 227 e 228, Blumenau e Itajaí, respectivamente) no litoral norte de Santa Catarina, o que não possibilita afirmar que se trata de uma forma regional de Minas.

No entanto, a variante china, com a acepção para bolinha de gude, fora documentada apenas em Minas, na mesma área geográfica em que o EALMG registrou, em Pedra Azul (ponto 129), Vale do Mucuri, não estando documentada em Romano (2015), Portilho (2013) e Ribeiro (2012).

\section{Estilingue e suas variantes}

A questão 157 do QSL apresentou um total de 119 registros distribuídos em 12 itens: estilingue (76 registros), bodoque (12), badoque (7), atiradeira (5), tiradeira (5), estilinga (4), estilingo (3), setra (3), ganchinho (1), bodogue (1), pilota (1) e garrote (1).

Agrupando as variantes morfofonêmicas de estilingue, bodoque e atiradeira, em dados percentuais, tem-se a seguinte distribuição (Gráfico 3):

Gráfico 3 - Produtividade das variantes lexicais para a questão 157 em MG.

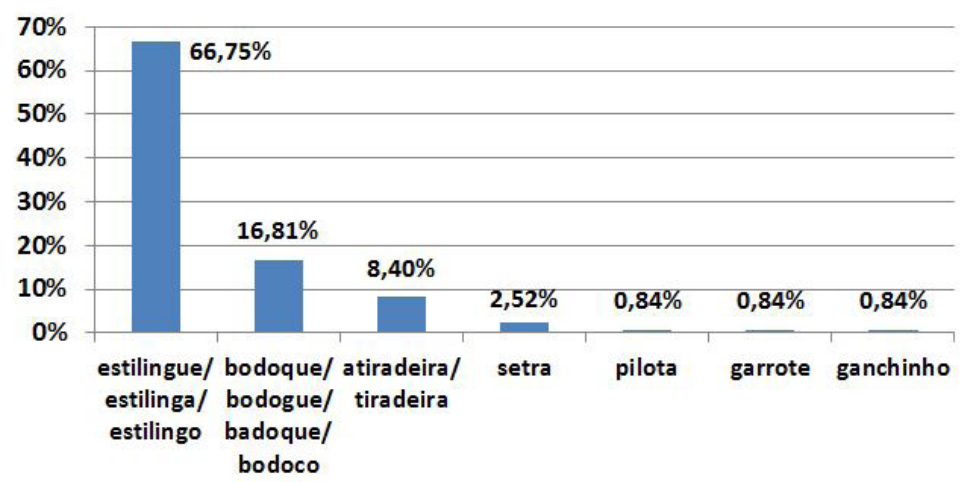

Fonte: Banco de dados do ALiB (2015). 
Observa-se no Gráfico 3 que o item lexical mais produtivo é estilingue e suas variantes morfofonêmicas (66,75\%), seguindose de bodoque e variantes (16,81\%) e atiradeira/tiradeira $(8,40 \%)$. Em menor produtividade encontra-se setra $(2,52 \%)$ e, como hápax legomena (0,84\%), pilota, garrote e ganchinho. Na Figura 8, observa-se a distribuição diatópica desses itens lexicais.
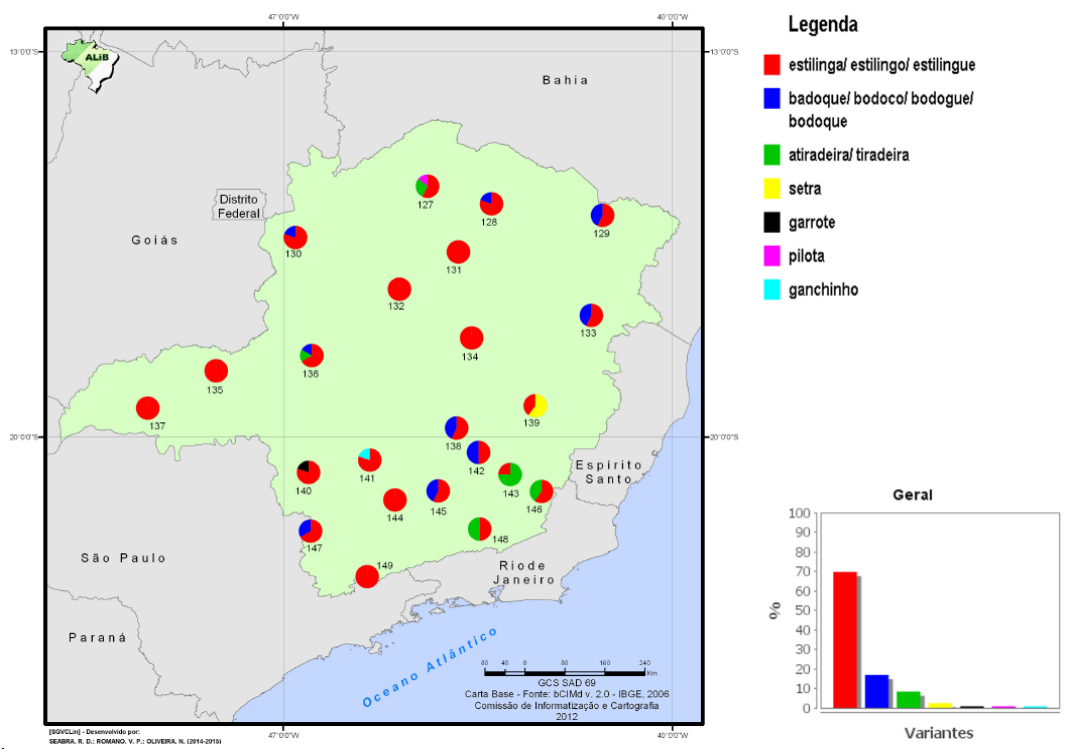

Figura 8 - Distribuição diatópica das variantes lexicais para a questão 157 do QSL

Fonte: Banco de dados do ALiB (2015)

A variante mais produtiva do corpus está amplamente difundida pelo território mineiro, representando $100 \%$ das respostas em 7 dos 23 pontos linguísticos investigados: pontos 131 (Montes Claros), 132 (Pirapora), 134 (Diamantina), 135 (Uberlândia), 137 (Campina Verde), 144 (Lavras) e 149 (Itajubá). O item bodoque ocorre em localidades do norte do estado, pontos 128 (Janaúba), 129 (Pedra Azul), 130 (Unaí), 133 (Teófilo Otoni), em localidades do centro de Minas Gerais: 138 (Belo Horizonte), 142 (Ouro Preto), 145 (São João del Rei), além de figurar em uma localidade do Triângulo Mineiro, ponto 136 (Patos de Minas), e no sul de Minas, no ponto 147 (Poços de Caldas). 
A variante atiradeira/tiradeira apresenta-se representativamente na região da Zona da Mata: pontos 143 (Viçosa), 146 (Muriaé) e 148 (Juiz de Fora), além de ocorrer, com menor produtividade, em Patos de Minas (ponto 136) e Januária (ponto 128), Triângulo Mineiro e norte de Minas, respectivamente. Setra ocorre, exclusivamente, em Ipatinga (ponto 139) representando mais de $50 \%$ de produtividade. Por fim, o item lexical garrote foi registrado apenas em Passos (ponto 140), ganchinho, em Formiga (ponto 141) e pilota, unicamente em Januária (ponto 127).

Considerando a produtividade das variantes segundo a variável faixa etária, observa-se o seguinte panorama (Gráfico 4):

Gráfico 4 - Produtividade das variantes para a questão 157 segundo a variável faixa etária

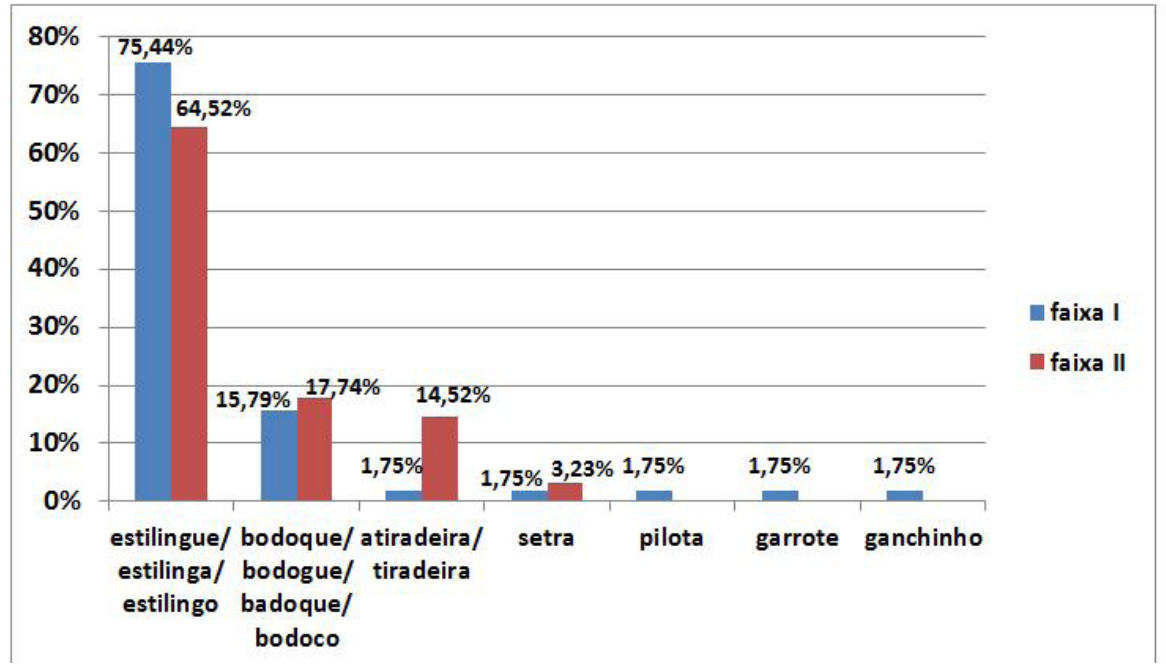

Fonte: Banco de dados do ALiB (2015)

Segundo a distribuição por faixa etária, observa-se que o item estilingue encontra-se mais produtivo entre os informantes da faixa I $(75,44 \%)$, ao passo que o percentual decresce em relação aos informantes da faixa II $(64,52 \%)$. Por outro lado, bodoque é mais representativo entre os informantes da faixa II (17,74\%), embora a produtividade entre os informantes da faixa I $(15,79 \%)$ apresente uma diferença de apenas $2 \%$, aproximadamente, comparando-se ambas as faixas etárias. 
Encontra-se certa diferença na ocorrência do item atiradeira/ tiradeira que, entre os informantes da faixa II, representa 14,52\%; enquanto entre os informantes da faixa I, esta representatividade é de apenas 1,75\%. Com o mesmo percentual, encontra-se setra entre os informantes da faixa etária mais nova, ao passo que esse item representa 3,23\% das respostas entre os da faixa II. Com pequena representatividade, pilota, garrote e ganchinho figuram apenas entre os informantes da faixa etária I (1,75\%).

Observa-se, contudo, certa divergência entre os informantes quanto ao uso de bodoque para designar o estilingue. Há aqueles que consideram sinônimos e há aqueles que identificam bodoque como outro referente, conforme se observa em relatos dos informantes transcritos ipsis litteris a seguir:

Informante 3, homem da faixa etária II, de Januária (Ponto 128):

INQ.- Tem outro nome para isso?

INF.- Não. Tem outro, mas é diferente. Bodoco, já viu falá em bodoco?

INQ.- Como é o bodoco?

INF.-Bodoco cêfaiz de pau, que o estilingo, né, faiz de pau e marra [=amarra] dois cordão, né, faiz o bodoco. Mais nome de bodoco, tem o bodoco e estilingo.

INQ.- Mas é diferente, pelo o que o senhor falou...

INF.- É, que um de gancho e outro é um só.

Informante 4, mulher da faixa etária II, de Pedra Azul (Ponto 129):

INF.- Estilingue.... Bodoque chamado. Bodoque tem aquele grande, e tem esse estilingue de matá bicho.

INQ.- Bodoque então é um pouco diferente?

INF.- É. O bodoque é diferente. O bodoque ele é feito de uma vara, muito, só pra quem sabe fazê, hoje não se usa mais. E igual uma flecha... faz duas linha. Faz a malha e coloca as pedra e puxa.

INQ.- Então é bem diferente...

INF.- Antigamente existia muito.

INQ.- Esse que a gente está querendo...

INF.- Esse ai é estilingue.

INQ.- Da forquilha é o estilingue?

INF.- É o estilingue. 
Informante 4, mulher, da faixa etária II, de Unaí (Ponto 130):

INF.- É... istilingue. Estilingue.

INQ.- Também não tinha outro nome?

INF.- Era istilingue ou bodoque, mais o bodoque era diferente um pouco, né, mas era...

INQ.- Como que é o bodoque?

INF.- O bodoque era um trem com um arco, ele era maior, né, um arco que... 'cê punha uma linha nele, né, a linha forçava ele emborcá, e 'cê punha uma pedra na, na linha, ti... no lugar... e punha trêis, trêis linhas assim, né, lá no bo... [?=bodoque], no pau fazia trêis... trêis coisinha aqui e punha trêis linha, daqui cá embaixo, né, e no meio fazia assim um teciduzim [= tecidozinho], de jeito, fazia uma... parecendo que fez uma... fez um coisa mais, mais... mais... no lugá assim como se ele tivesse feito um croché naquele lugar assim mais fechado, ai 'cê punha a pedra no, e puxava assim e mirava num lugar e soltava a pedra. É quase igual o estilingue, mais são em nomes diferente, né, bodoque e estilingue.

INQ.- Que interessante.

INF.- Iss'aí os menino na, na roça, os menino meu, meus irmão tudo brincava muito com isso, matava Passarim [= passarinho], muito com essas coisa.

No cômputo das respostas válidas para bodoque e variantes morfofonêmicas, foram consideradas apenas aquelas em que o informante confirma tratar-se do mesmo referente, embora considere como uma forma antiga para denominar o atual estilingue. Há informantes que identificam bodoque como outra denominação para o mesmo objeto, conforme se observa nos relatos a seguir:

Informante 3, homem da faixa etária II, de Janaúba (ponto 128):

INF.- Estilingo.

INQ.- Como?

INF.- Estilingo.

INQ.- Ainda brinca aqui disso?

INF.- Hunhun.

INQ.- Tem outro nome? 
INF.- Tem, o povo falava badoque também (rindo), né os antigo, usa mais é estilingo.

INQ.- Os antigos que falavam badoque?

INF.- É.

INQ.- $A$ h, ta.

Informante 1, homem da faixa etária I, de Pedra Azul (Ponto 129):

INF.- Badoque.

INQ.- Tem outro nome para badoque?

INF.- Estilingue.

INQ.- É a mesma coisa? Igualzinho assim de forquilha assim com elástico.

INF.- É, igualzinho. O estilingue com badoque é mesma... Mesma coisa mesma.

INQ.- Pega um galhinho e faz.

Informante 1, homem da faixa etária I, de Teófilo Otoni (ponto 133):

INQ.- Tem outro nome?

INF.- Bodogue.

INQ.- Qual que usa mais?

INF.- Estilingue.

INQ.- Os dois são iguaizinhos?

INF.- São a mesma coisa.

INQ.- Só que usa mais...

INF.- $O$ estilingue.

INQ.- Você acha que bodogue alguém usava antes...

INF.- É, o pessoal mais antiga usava bodogue, né. Hoje eu vejo algumas pessoas falá, mas é muito difícil, é mais estilingue mesmo.

Informante 4, mulher da faixa etária II, de Teófilo Otoni (ponto 133):

INF.- Bodoque... Estilingue, quer dizer.

INQ.- Qual usa mais? Estilingue ou bodoque?

INF.- Usa mais estilingue aqui.

INQ.- E a senhora conheceu bodoque onde? 
INF.- Óia eu sempre faço pros meu neto e meus fio que fazia.

INQ.- Então a senhora chamava de bodoque?

INF.- Era.

INQ.- E hoje é que o povo chama de estilingue, é isso?

INF.- É. Ai tem dois nome, dois nome.

Informante 3, homem da faixa etária II, de Ouro Preto (Ponto 142):

INF.- Aquilo ali tinha diversos nome. Lá na roça a gente tratava aquilo ali como fosse um bodoque. Agora, aqui, hoje já mudaro [=mudaram] muito, chama de estilingue.

Embora os informantes que confirmam bodoque ser o mesmo referente, apresentando apenas comentários diageracionais acerca do uso do vocábulo, observa-se que não há diferença relevante entre as duas faixas etárias (Gráfico 4), estando presente tanto na fala dos mais jovens quanto dos mais velhos, com percentuais abaixo de $20 \%$ das respostas. Nesse caso, a variação em tempo aparente evidencia a variação linguística estável quanto ao uso de bodoque.

Contudo, quanto ao uso do item atiradeira/tiradeira, os informantes não forneceram mais detalhes sobre essa variante, embora se observe no Gráfico 4 a predominância dessa forma lexical entre os informantes com mais idade (faixa II).

A partir da Figura 9, que retrata a carta linguística 43 do EALMG, observa-se a ocorrência da variante mais produtiva no corpus em todo o estado mineiro (estilingue), representada pelo item em azul da legenda; enquanto atiradeira e setra definem áreas lexicais delimitadas pelas linhas traçadas na carta original.

Observa-se na carta do EALMG, adaptada com as linhas de isoléxicas de atiradeira e seta, que a primeira variante apresentava-se amplamente distribuída pela região da Zona da Mata, ocorrendo também no centro-oeste de Minas, ponto 50 (Bambuí), em duas localidades do centro mineiro, pontos 16 (Curvelo) e 17 (Diamantina), e em uma área do norte de Minas Gerais (ponto 1, Januária, 1A, Janaúba; ponto 7, Coração de Jesus, e 9 Montes Claros).

Seta, por sua vez, a partir de uma área de confluência na Zona da Mata em que ocorre com atiradeira (pontos 59 e 69: Caratinga e 
Manhumirim, respectivamente) caminha em direção ao Vale do Rio Doce até o sudeste do Vale Mucuri (ponto 23 - Nanuque), além de ocorrer isoladamente em Cordisburgo (ponto 52), no centro do estado (região metropolitana de Belo Horizonte).

A Figura 10 apresenta as áreas lexicais dos itens no corpus do ALiB.

Comparando-se ambas as cartas (figuras 9 e 10), observa-se que nos dados do ALiB a área de ocorrência de atiradeira/tiradeira ainda se mantém predominantemente na Zona da Mata, embora com menor abrangência, possivelmente devido à rede de pontos menos densa do atlas nacional, assim como a ocorrência do item na região norte do estado, em Januária (ponto 127). Contudo, há de se notar, nos dados atuais, que o item atiradeira ocorre também em Patos de Minas (Triângulo Mineiro/ Alto Paranaíba), o que não ocorria nos dados de 1970.

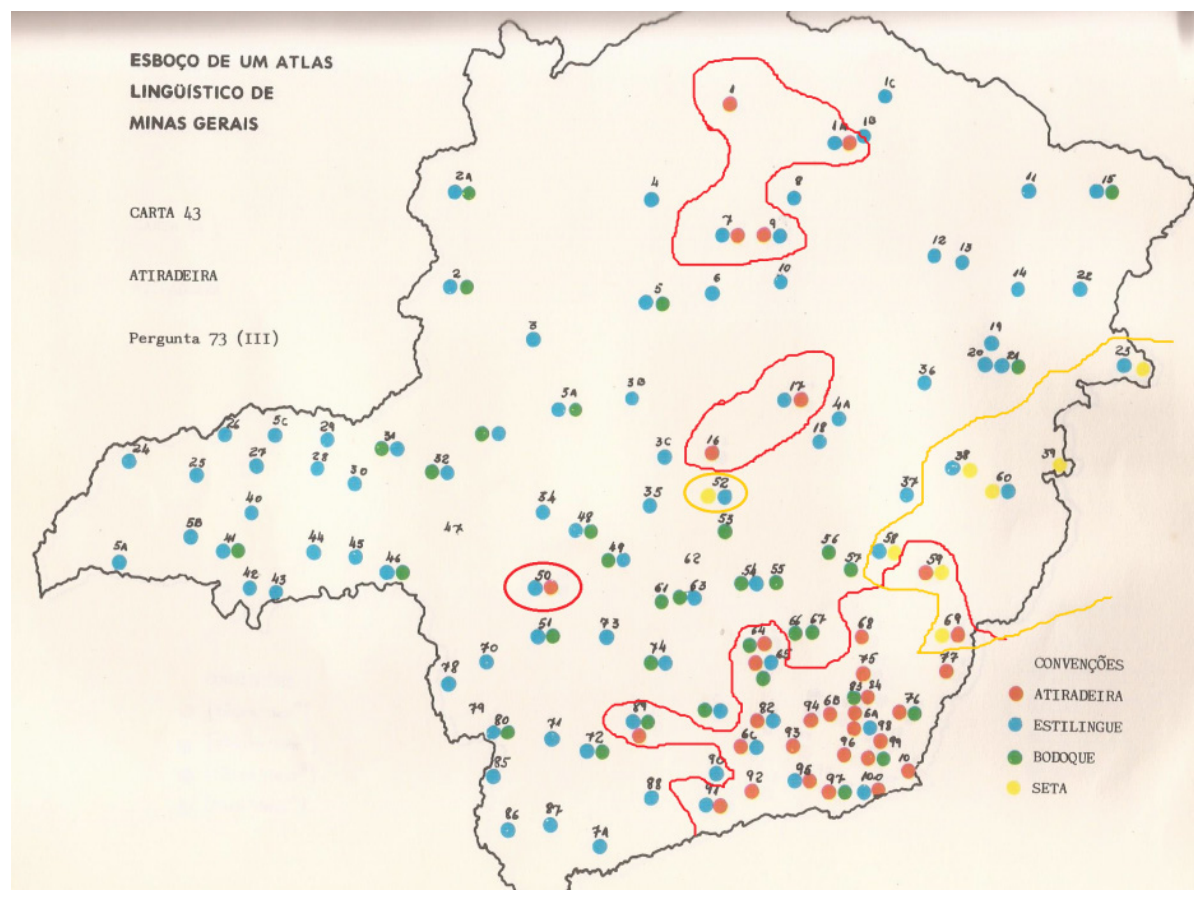

Figura 9 - Carta linguística 43 do EALMG: isoléxicas de atiradeira e seta Fonte: Ribeiro et al. (1977) - adaptada 


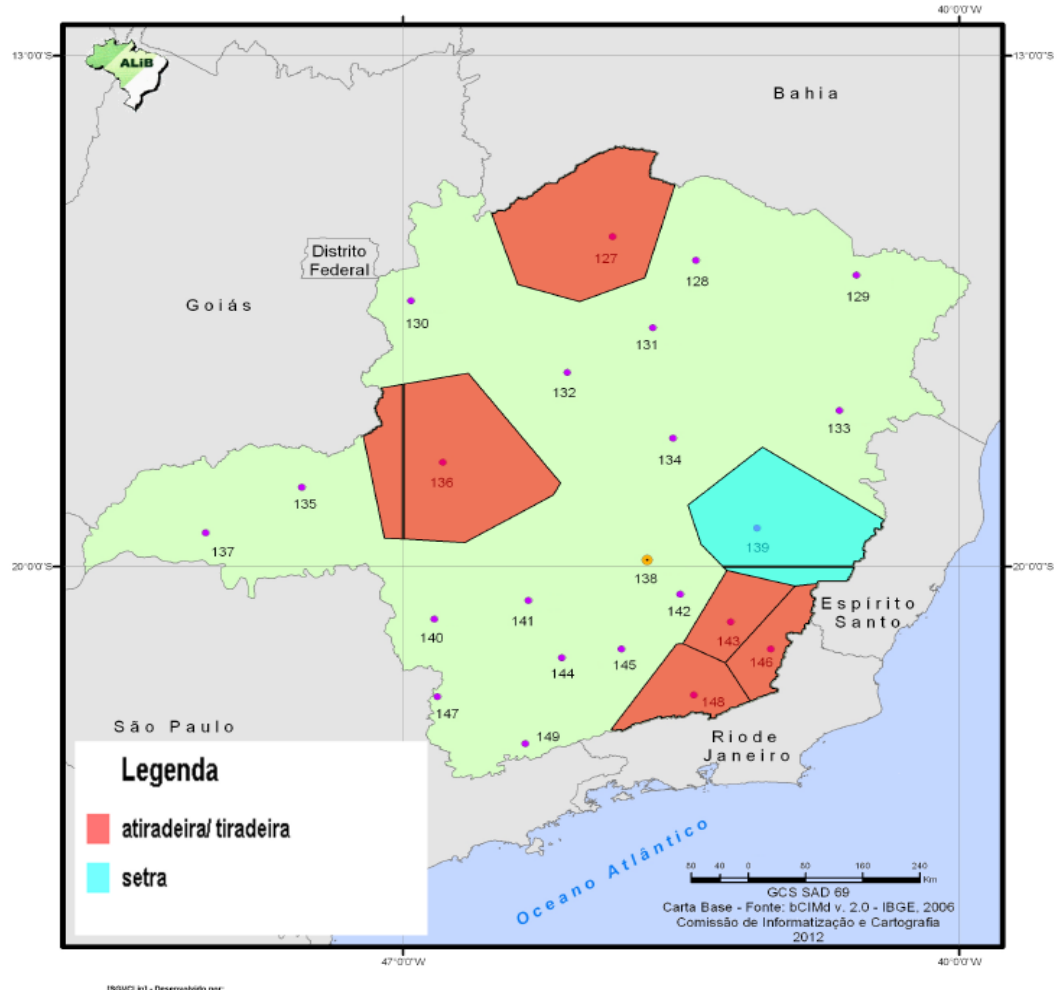

Figura 10 - Áreas lexicais de atiradeira/tiradeira e setra Fonte: Banco de dados do ALiB (2015)

Quanto à variante seta, que nos dados do ALiB ocorre somente com a variante fonética setra, observa-se representativa produtividade em Ipatinga, ponto 139, representando $60 \%$ das respostas válidas dos ipatinguenses. Esse município mineiro está localizado no Vale do Rio Doce, confirmando nos dados atuais a área de ocorrência nessa região do estado (Figura 9). Acredita-se que nos dados do ALiB a mesma justificativa sobre a densidade da rede de pontos pode ser levada em consideração ao verificar a área de abrangência do item.

Em Ribeiro (2012), encontra-se setra documentada nos pontos 188 (Barra do São Francisco) e 189 (São Mateus), no extremo norte do Espírito Santo, sem, contudo, adentrar o território baiano, o que 
dá indícios de uma variante que possivelmente caracterizaria o falar fluminense e sua influência nos estados de Minas Gerais e Espírito Santo.

Sobre a variante bodoque, a Figura 11 ilustra a isoléxica para o item nos dados do EALMG.

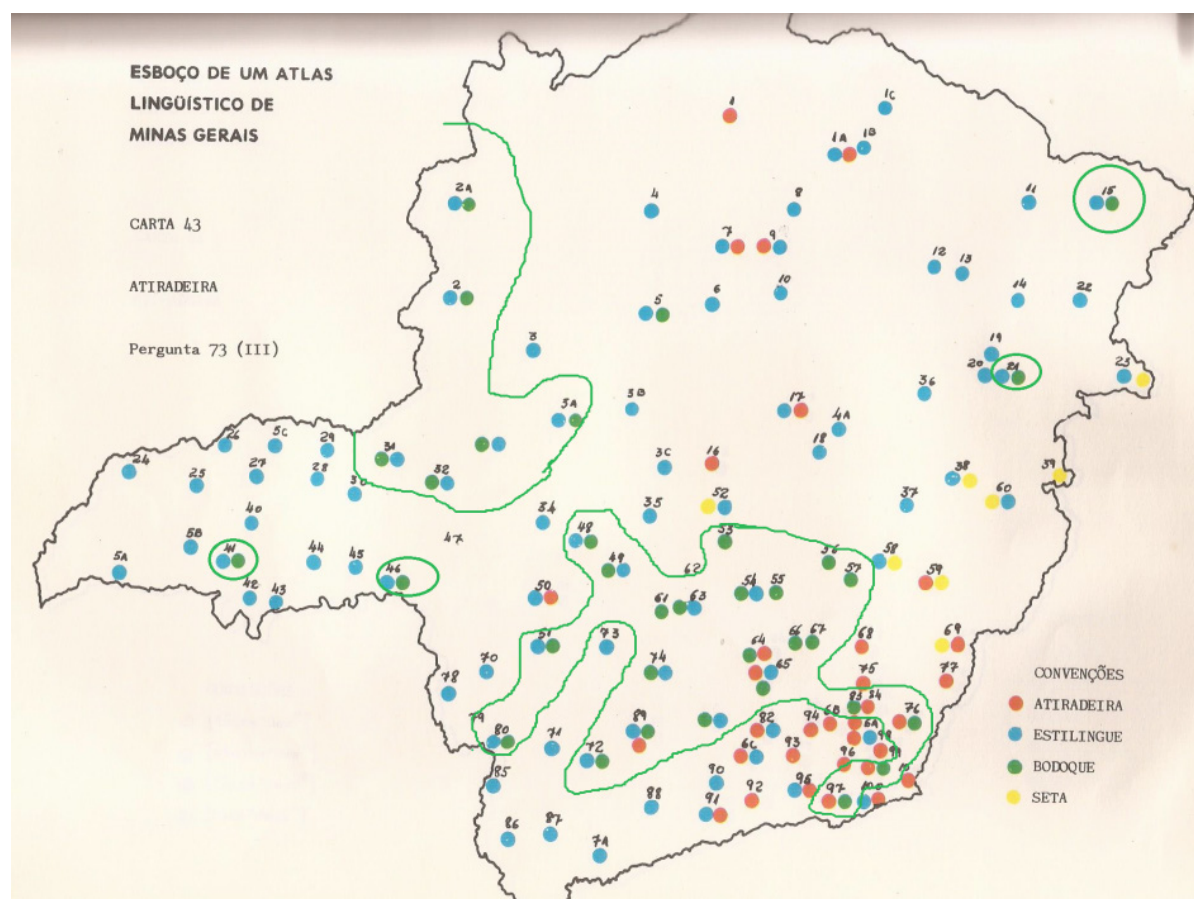

Figura 11 - Carta linguística 43 do EALMG: isoléxica de bodoque Fonte: Ribeiro et al. (1977) - adaptada

$\mathrm{Na}$ carta do EALMG, adaptada com as linhas de isoléxicas para bodoque, verifica-se a predominância do item na mesorregião do Campo das Vertentes, contemplando Lavras (ponto 89) e São João del Rei, ponto 81, que no mapa, por erro gráfico, não está impresso. Essa isoléxica abrange também a mesorregião metropolitana de Belo Horizonte, como em Sabará, (ponto 55) e Itabira (ponto 56), a mesorregião central mineira (Dores do Indaiá - ponto 48), passando pela mesorregião oeste mineira (Piumhi, ponto 51) até a mesorregião sul e sudoeste de Minas, (Muzambinho, ponto 80, e Varginha, ponto 72). 
Há ocorrência do item no Triângulo Mineiro, Comendador Gomes (ponto 41) e Sacramento (ponto 46), São Gotardo (ponto 34) e Patrocínio (ponto 32), de onde se irradia atingindo o noroeste de Minas (Unaí, ponto 2A), além de ocorrências isoladas no Vale do Jequitinhonha (ponto 15, Almenara) e no Vale do Mucuri (ponto 21, Teófilo Otoni).

A Figura 12 apresenta as áreas de ocorrência do item bodoque e variantes morfofonêmicas segundo a produtividade em cada área considerando os dados atuais.

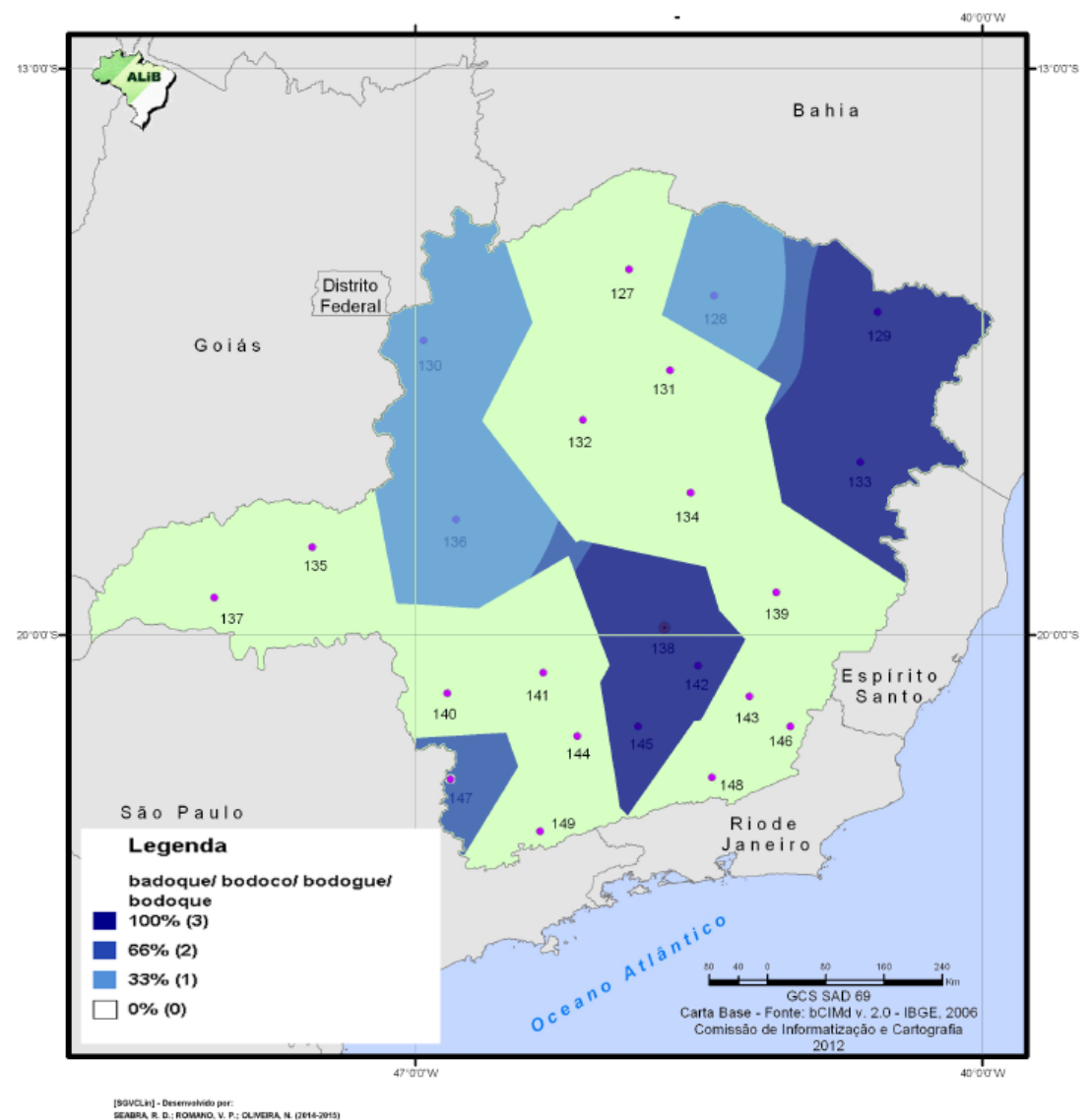

Figura 12 - Áreas lexicais de bodoque nos dados do ALiB, segundo a produtividade

Fonte: Banco de dados do ALiB (2015) 
Pode-se observar que há certa coincidência entre os dois corpora (ALiB e EALMG) quanto às áreas lexicais de bodoque. Contudo, não é possível afirmar que essa variante caracteriza uma área lexical exclusiva de Minas Gerais, pois, em Ribeiro (2012), há a constatação da ampla distribuição do item no território baiano.

No território mineiro, bodoque atualmente encontra-se mais significativamente representado em localidades de quatro mesorregiões do estado: metropolitana de Belo Horizonte (ponto 138 - Belo Horizonte e 142 - Ouro Preto), parte do Campo das Vertentes (ponto 145 - São João del Rei), no Vale do Mucuri (ponto 133 - Teófilo Otoni) e no Vale do Jequitinhonha (ponto 129 - Pedra Azul,), cuja ocorrência máxima por ponto, para o item, representou três registros.

Em menor produtividade (66\%), encontra-se a variante em Poços de Caldas (ponto 147 - sul de Minas) e do Triângulo Mineiro (Patos de Minas - ponto 136) a Unaí (ponto 130, na mesorregião noroeste de Minas) bodoque ocorre com o registro de 33\%. Janaúba (ponto 128), norte de Minas, apresenta o mesmo percentual.

Ao comparar ambos os corpora (figuras 11 e 12), observa-se que as áreas lexicais ainda se mantêm no território mineiro no que se refere à distribuição diatópica do item bodoque, embora no $\mathrm{ALiB}$ apresente-se de forma pouco mais reduzida devido ao fato já referido da densidade da rede de pontos.

\section{Considerações finais}

A proposta de Zágari (1998) sobre a tripartição do território mineiro em três falares, considerando os corpora analisados, não se confirma sob o ponto de vista lexical, conclusão já preconizada por Rocha (2012) e ratificada por esta pesquisa que se pautou em dados empíricos.

Entre o rol de variantes documentadas para ambas as questões e em ambos os atlas não se encontrou uma forma que caracterizaria o chamado falar paulista (sul e Triângulo Mineiro) e o baiano (norte do estado), nem mesmo o mineiro, caracteristicamente.

Embora a variante china, para bolinha de gude, ocorra exclusivamente no noroeste mineiro, observa-se que o item não está documentado no território baiano, conforme constatou o estudo de Ribeiro (2012), o que ratifica a importância de um trabalho mais específico acerca dessa área do território de Minas Gerais (Vale do 
Mucuri e do Jequitinhonha), tendo em vista a presença do item nos dados do EALMG que ainda persistem nos dados do ALiB (mais de $60 \%$ das respostas em Pedra Azul - ponto 129).

Quanto ao falar mineiro, não se encontraram variantes que se revelem exclusivas de Minas Gerais, pois algumas delas estão registradas em áreas do Espírito Santo, como se verifica com boleba, para bolinha de gude, presente em localidades capixabas, além de setra e atiradeira, para estilingue, com o mesmo comportamento.

É notável que há variantes que figuram tipicamente na fronteira de Minais com Espírito Santo e Rio de Janeiro, mas se fazem necessários mais estudos para verificar esta área geográfica. Estaria o território mineiro recebendo influência do falar fluminense? Ou seria Minas Gerais que tem seus limites 'linguajeiros' expandidos para outras áreas?

Contudo, não há dúvida de que o item bilosca poderia indicar e caracterizar uma possível influência de mineiros, sobretudo, no noroeste e oeste do estado de São Paulo, além de influências do sudoeste de Goiás, conforme apontamentos já feitos por Romano (2015), o que se evidencia pelas isoléxicas que não seguem limites físicos, e sim sócio-históricos.

Isso coaduna com a ideia defendida por Romano (2015), pois estabelecer áreas dialetais a partir de dados lexicais tem se mostrado uma tarefa desafiadora, contudo, só "são possíveis de serem definidas, considerando os aspectos sociais e históricos envolvidos na configuração diatópica de determinada região, e levando em conta fatores tais como migração e imigração, que, indubitavelmente, interferem na disseminação de variantes" (p. 265).

Os dados atuais têm revelado que algumas variantes indicam a variação diageracional, evidenciando uma mudança em progresso. É o caso de formas como bilisco, biroquê, bolinha de vidro e bolinha de clique, que, no EALMG, apresentavam distribuição diatópica mais ampla e, atualmente, se encontram em poucas ocorrências, apenas entre os informantes da faixa etária II.

Conjugar o estudo em tempo real ao de tempo aparente possibilita uma visualização mais coerente do processo de mudança e variação linguística. Mas, muito mais do que isso, essas formas alternantes, 'petrificadas' na história da língua pelos atlas linguísticos, evidenciam a própria história das mudanças sociais. Chegará o tempo em que a boleba e a atiradeira não mais serão reconhecidas, ou que a china e a setra constarão apenas na memória como peças de museus, considerando a 
dinâmica social em que padrões de brinquedos eletrônicos ou mesmo de diversões infantis já estão modificados.

\section{Referências}

AGUILERA, V. de A. Atlas Linguístico do Paraná. Curitiba: Imprensa Oficial, 1994.

AMARAL, E. T. R. (Org.). O português falado em Minas Gerais. Belo Horizonte: UFMG, 2013.

ARAGÃO, M. do S. S. de; BEZERRA DE MENEZES, C. Atlas Linguístico da Paraíba. Brasília: UFPB, 1984.

CARDOSO, S. A. M. S. Geolinguistica: tradição e modernidade. São Paulo: Parábola Editorial, 2010.

CARDOSO, S. A. M. S. et al. Atlas Linguístico do Brasil. Vol. 1 (Introdução). Londrina: EDUEL, 2014a.

. Atlas Linguístico do Brasil. Vol. 2 (cartas Linguísticas).

Londrina: EDUEL, 2014b.

CARDOSO, S. A. M. S.; MOTA, J. A.; PAIM, M. M. T.; RIBEIRO, S. S. C. Documentos 4: Projeto Atlas Linguístico do Brasil. Salvador: Vento Leste, 2013.

CARRETER, F. L. Diccionário de términos filológicos. Madrid: Gredos, 2008.

CARUSO, P. Atlas Linguístico do Estado de São Paulo: Questionário. Assis: Instituto de Letras, História e Psicologia/UNESP, 1983.

COHEN, M. A. A. M.; RAMOS, J. M. (Orgs.). Dialeto mineiro e outras falas: estudos de variação e mudança linguística. Belo Horizonte: UFMG, 2002.

COMITÊ NACIONAL DO PROJETO ALiB. Questionários 2001. Londrina: Eduel, 2001.

CORDEIRO, M. J. Estudo linguístico no Vale do Jequitinhonha: o léxico de Minas Novas. 2013. 291p. Dissertação (Mestrado em Estudos Linguísticos) - Universidade Federal de Minas Gerais, Belo Horizonte, 2013.

COSERIU, E. O homem e a sua linguagem. Tradução de Carlos Alberto da Fonseca e Mário Ferreira. Rio de Janeiro: Presença, 1987. 
DOGLIANI, E.; COHEN, M. A. M. (Orgs.). Pelas trilhas de Minas: a língua nas Gerais. Belo Horizonte: UFMG, 2011.

ENCONTRO SOBRE A DIVERSIDADE LINGUÍSTICA DE MINAS GERAIS - DIVERMINAS, 2010, Ouro Preto. Anais...cultura e memória. Belo Horizonte: UFMG, 2011.

FREITAS, C. J. de. O léxico da Serra do Cipó. In: ENCONTRO SOBRE A DIVERSIDADE LINGUÍSTICA DE MINAS GERAIS, 2010, Ouro Preto. Anais... cultura e memória. Belo Horizonte: UFMG, 2011. p. 181185. 1 CD-ROM.

LABOV, W. Principios del cambio lingüístico. Vol. 1 (factores internos). Traducción Pedro Martín Butragueño (versión española). Madrid: Gredos, 1996.

MARGOTTI, F. W. O português em contato com o italiano no sul do Brasil: um estudo geolinguístico pluridimensional. In: AGUILERA, V. de A.; ROMANO, V. P. (Orgs.). A Geolinguística no Brasil: caminhos percorridos, horizontes alcançados. vol. 3. Londrina: EDUEL. (no prelo). MIRANDA, V. M. R. de. Léxico e cultura: estudo linguístico na área rural de Sibianópolis-MG. 2013. 263p. Dissertação (Mestrado em Estudos Linguísticos) - Universidade Federal de Minas Gerais, Belo Horizonte, 2013.

NASCENTES, A. O linguajar carioca. 2. ed. Rio de Janeiro: Organizações Simões, 1953.

NICOLAU, E. Pelas trilhas de Minas até Belo Vale: garimpando em busca de traços conservadores do português do Brasil. In: DOGLIANI, E.; COHEN, M. A. A. M. (Orgs.). Pelas trilhas de Minas: a língua nas Gerais. Belo Horizonte: UFMG, 2011. p. 145-162.

OLIVEIRA, D. G. de (Org.) ALMS - Atlas Linguístico do Mato Grosso do Sul. Campo Grande: Editora UFMS, 2007.

PAIVA, M. da C. de; DUARTE, M. E. L. Introdução: mudança linguística em curso. In: . (Orgs.). Mudança linguística em tempo real. Rio de Janeiro: Contra Capa, 2003. p. 13-29.

PORTILHO, D. A. S. O falar amazônico: uma análise da proposta de Nascentes (1953) a partir de dados do Projeto ALiB. 2013. 155p. Dissertação (Mestrado em Estudos de Linguagens) - Universidade Federal do Mato Grosso do Sul, Campo Grande, 2013. 
RAMOS, J. M.; COELHO, S. M. (Orgs.). Português brasileiro dialetal: temas gramaticais. Campinas: Mercado das Letras, 2013.

RIBEIRO, G. A. O vocabulário rural de Passos/Minas Gerais: um estudo linguístico nos sertões do Jacuhy. In: ENCONTRO SOBRE A DIVERSIDADE LINGUÍSTICA DE MINAS GERAIS, 1., 2010, Ouro Preto. Anais... cultura e memória. Belo Horizonte: UFMG, 2011. p. 194201. 1 CD-ROM.

RIBEIRO, J. et al. Esboço de um atlas linguístico de Minas Gerais. Rio de Janeiro: Casa de Rui Barbosa, 1977.

RIBEIRO, S. S. C. Brinquedos e brincadeiras infantis na área do falar baiano. 2012. 466p. Tese (Doutorado) - Universidade Federal de Bahia, Salvador, 2012.

ROCHA, A. P. A. Notas sobre o léxico de brincadeiras infantis usado em Minas Gerais à Luz de dois trabalhos geolinguísticos: o ALEMiG (1977) e o Projeto ALiB. In: ALTINO, F. C. (Org.). Múltiplos olhares sobre a diversidade linguística: uma homenagem à Vanderci de Andrade Aguilera. Londrina: Midiograf, 2012. p. 79-92.

ROCHA, A. P. A.; ANTUNES, L. B. Divisão dialetal em Minas Gerais: notas sobre aspectos fonéticos. In: RAZKY, A.; LIMA, A. F. de.; OLIVEIRA, M. B.; COSTA, E. O. da. (Orgs.). Estudos sociodialetais do português brasileiro. Campinas: Pontes, 2014. p. 97-111.

ROCHA, A. P. A.; RAMOS, J. M. Estudos dialetais em Minas Gerais. Estudos linguísticos e literários, Salvador, n. 41, p. 70-86, jan./jun. 2010.

ROMANO, V. P. Balanço crítico da geolinguística brasileira e a proposição de uma divisão. Entretextos, Londrina, v. 13, n. 2, p. 203-242, jul./dez. 2013.

. Em busca de falares a partir de áreas lexicais no centro-sul do Brasil. 2015. 2v. Tese (Doutorado em Estudos da Linguagem) Universidade Estadual de Londrina, Londrina, 2015.

ROMANO, V. P.; SEABRA, R. D.; OLIVEIRA, N. [SGVCLin] Software para geração e visualização de cartas linguísticas. RELin: Revista de Estudos da Linguagem, Belo Horizonte, v. 22, n. 1, p. 119-151, 2014. Disponível em: <http://www.periodicos.letras.ufmg.br/index.php/ relin/article/view/5757>. Acesso em: 20 set. 2015. 
ROSSI, N. et al. Atlas prévio dos falares baianos. Rio de Janeiro: INL, 1963.

SANTOS, L. S. M. O léxico de remanescentes de comunidades garimpeiras do Alto Jequitinhonha. 2015. Tese (Doutorado em Estudos Linguísticos) - Universidade Federal de Minas Gerais, Belo Horizonte, 2015.

SEABRA, M. C. T. C. de. (Org.). Léxico em estudo. Belo Horizonte: UFMG, 2006.

SOUZA, V. L. de. Nas cacimbas do rio Pardo: um estudo léxico-cultural. 2014. 621p. Tese (Doutorado em Estudos Linguísticos) - Universidade Federal de Minas Gerais, Belo Horizonte, 2014.

TARALLO, F. A pesquisa sociolinguística. 6. ed. São Paulo: Ática, 1999. (Série Princípios).

TEIXEIRA, J. A. O falar mineiro. Revista do Arquivo Público Municipal, São Paulo, v. XLV, 1938.

THUN, H. La géographie linguistique romane à la fin du XX siècle. In: XXII CONGRES INTERNATIONAL DE LINGUISTIQUE E PHILOLOGIE ROMANES, BRUXELLES, 1998. Actes ... Bruxelles, 1998, p. 367-409.

VIEGAS, M. do C. (Org.). Minas é plural. Belo Horizonte: UFMG, 2011. ZÁGARI, J. R. L. Os falares mineiros: esboço de um atlas linguístico de Minas Gerais. In: AGUILERA, V. de A. (Org.). A geolingüística no Brasil: caminhos e perspectivas. Londrina: EDUEL, 1998. p. 31-54.

. Os falares mineiros: esboço de um atlas linguístico de Minas Gerais. In: AGUILERA, V. de A. (Org.). A geolingüística no Brasil: trilhas seguidas, caminhos a percorrer. Londrina: EDUEL, 2005. p. 46-72. 